\title{
“ACEITE A BENÇÃO E UM APERTADO ABRAÇO DE SUA CARINHOSA MÃE”: ESCRAVIDÃO, DIÁSPORAS E A PERENIDADE DOS LAÇOS FAMILIARES (Porto Alegre, Salvador, século XIX)
}

Paulo Staudt Moreira (D) $\nabla$

Universidade do Vale do Rio dos Sinos

O afloramento ininterrupto do singular convida a pensar "o único", a refletir sobre o conceito histórico de "indivíduo" e a tentar uma difícil articulação entre as pessoas anonimamente mergulhadas na história e uma sociedade que as contém. (Arlette Farge, O sabor do arquivo, São Paulo: Edusp, 2009, p. 90)

\footnotetext{
7 m uma célebre polêmica historiográfica ocorrida no século passado, discutiu-se a pluralidade das experiências escravistas e a teoria do escravo-coisa, surgindo a acusação de que alguns historiadores estariam com isso reabilitando a escravidão. Ou seja, pesquisas que procuravam complexificar as experiências sociais do cativeiro estariam, ao contrário, defendendo que era bom ser escravo no Brasil. Segundo a historiadora Silvia Lara:
}

Suas histórias mostram como seres humanos submetidos à escravidão tinham valores e projetos - diferentes daqueles de seus senhores - e lutaram por eles enquanto escravos. Construíram alternativas de vida, lutaram de diversas formas e conquistaram “direitos”, transformando as próprias relações de dominação a que estavam submetidos. Suas ações e valores só podem ser compreendidos no interior e através das relações sociais tecidas por eles e seus senhores. Deixar de lado 
noções anacrônicas de violência e liberdade significa apenas dar voz para esses homens e mulheres afirmarem suas concepções a respeito destas palavras. Podemos aprender com eles que a liberdade não significa vender sua força de trabalho, mas sim ter o direito de ir e vir, ter acesso à terra, manter linhagens e laços de solidariedade arduamente construídos. ${ }^{1}$

A impressão que fica deste debate é que, se pluralizarmos e densificarmos as experiências sociais da vida em cativeiro e em liberdade, estaremos atenuando a violência da escravidão e da desigualdade racial na sociedade brasileira. Entretanto, as pesquisas dos últimos anos evidenciaram que resistência e opressão são faces que se mesclaram de forma diversificada na sociedade escravista e que a diáspora atlântica, na heterogeneidade de suas vítimas, provocou complexos e estratégicos hibridismos identitários. Luis Nicolau Parés sugere que:

Os africanos desenvolviam "estratégias de identidade”, nas quais os atores sociais, em função da situação, utilizavam seus recursos de identidade de maneira estratégica, geralmente com o intuito de atingir algum objetivo. Por exemplo, um escravo ou liberto podia identificar-se, dependendo do contexto e do interlocutor, como savalu, jeje, mina ou africano, indo da categoria mais particular à mais genérica. As diversas categorias de identidade funcionariam, por assim dizer, de forma superposta, ou como as bonecas russas encaixadas umas nas outras. ${ }^{2}$

1 Silvia Hunold Lara, “Gorender escraviza a história”, Folha de São Paulo, São Paulo, 12 jan. 1990. Sobre a polêmica, ver: Jacob Gorender, A escravidão reabilitada, São Paulo: Ática, 1990; “Como era bom ser escravo no Brasil”, Folha de São Paulo, São Paulo, 15 mar. 1992. Sidney Chalhoub, “Jacob Gorender põe etiqueta nos historiadores”, Folha de São Paulo, 24 nov. 1991; Visões da liberdade: uma história das últimas décadas da escravidão na corte, São Paulo: Companhia das Letras, 1990.

2 Luis Nicolau Parés, A formação do candomblé: história e ritual da nação jeje na Bahia, Campinas: Editora da Unicamp, 2007, p. 15. 
O objetivo deste artigo é analisar a continuidade e a estrutura dos laços familiares em situações de diáspora e desterritorialidade. A diáspora transatlântica não esgota a questão dos traumas e desvinculamentos acarretados pela escravidão. Trazidos para o Brasil escravizados, os africanos eram vítimas de transações mercantis que os faziam ir, com suas famílias aqui criadas, para diferentes províncias do Império, conforme as necessidades locais e os rumos do tráfico interprovincial. Alguns documentos, mesmo que residuais, nos permitem mesclar agência e estrutura na sociedade escravista, e pensar como os arranjos familiares e afetivos se mantinham. A ideia é acompanhar a trajetória de alguns indivíduos africanos e seus filhos crioulos, cogitando como eles construíam e mantinham seus arranjos afetivo-familiares.

Nossa narrativa será baseada em vicissitudes biográficas de algumas vítimas da diáspora transatlântica e de seus descendentes, procurando compor trajetórias individuais e familiares. Essas trajetórias afro-diaspóricas são marcadas, em suas narrativas historiográficas, pela fragmentação, mas isso não inviabiliza a sua utilização como método de apreensão da variedade das experiências sociais de escravizados e forros na sociedade brasileira oitocentista. Além disso, os indivíduos escravizados e forros, ao afirmarem sua subjetividade e humanidade numa sociedade que os tratava como objetos negociáveis, criavam e mantinham laços étnicos, familiares, de parentesco, de amizade, em cujos arranjos as famílias senhoriais não podiam ser desprezadas. Assim, a pesquisa de trajetórias nunca se refere a homens e mulheres sós, mas a "um indivíduo que concentra todas as características de um grupo”. 3

3 Giovanni Levi, A herança imaterial: trajetória de um exorcista no Piemonte do século XVII, Rio de Janeiro: Civilização Brasileira, 2000, p. 175. Ao longo do artigo citaremos outros exemplos do uso de trajetórias, mas neste momento destacamos: João José Reis, Domingos Sodré, um sacerdote africano: escravidão, liberdade e candomblé na Bahia do século XIX, São Paulo: Companhia das Letras, 2008. Alexandro Dantas Trindade, “André Rebouças: da engenharia civil à engenharia social”, Tese (Doutorado em Sociologia), Universidade Estadual de Campinas, Campinas, 2004. Daniela do Carmo Kabengele, “A trajetória do 'pardo’ Antonio Ferreira Cesarino (1808-1892) e o trânsito das mercês”, Tese (Doutorado em Antropologia Social), Universidade Estadual de Campinas, Campinas, 2012. Regina Celia Lima Xavier, Religiosidade e escravidão no século XIX: Mestre Tito, Porto Alegre: EDUFRGS, 2008. 


\section{O crioulo Sabino e seu pai Antônio, da costa da África}

Dezesseis anos antes da abolição da escravatura no Brasil (1888) e dois anos após o fim da Guerra do Paraguai (1870), foi fundada na capital da província de São Pedro do Rio Grande do Sul a Sociedade Beneficente Floresta Aurora. A Floresta Aurora, criada em 1872 e ainda hoje existente, foi a primeira associação não religiosa que congregou indivíduos negros nessa província sulina. Talvez o impacto da grande presença de soldados negros no conflito com a República Paraguaia tenha criado um clima propício para a fundação de uma sociedade com um explícito componente racial. ${ }^{4}$ Como sabemos, o conflito exigiu uma campanha de mobilização voluntária, já que o recrutamento compulsório não era suficiente para suprir os contingentes militares necessários. Isso permeou os "voluntários da pátria” de uma áurea de patriotismo (de um empoderamento, ainda que efêmero), mas, retornando do conflito, os soldados negros encontraram a persistência da escravidão e a emergência cada vez mais consistente do racismo científico. Essa atmosfera incentivou e permitiu a criação de sociedades como a Floresta Aurora, que potencializaram lutas antirracistas, visibilizando e dando voz a um consistente coletivo negro. ${ }^{5}$

A Floresta Aurora reunia indivíduos negros irmanados, entre outras coisas, pela música, ${ }^{6}$ eque atuavam emmomentos lúdicos, políticos e religiosos,

4 Sobre a Guerra do Paraguai, ver: Francisco Doratioto, Maldita guerra: nova história da Guerra do Paraguai, São Paulo: Companhia das Letras, 2002. Gabriela Nunes Ferreira, O rio da Prata e a consolidação do Estado imperial, São Paulo: Hucitec, 2006. Daniela Vallandro de Carvalho, "Fronteiras da liberdade: experiências negras de recrutamento, guerra e escravidão: Rio Grande de São Pedro, c. 1835-1850”, Tese (Doutorado em História Social), Universidade Federal do Rio de Janeiro, Rio de Janeiro, 2013.

5 João José Reis, Ganhadores: a greve negra de 1857 na Bahia, São Paulo: Companhia das Letras, 2019, p. 251.

6 Destaquemos que Porto Alegre tinha uma cena musical embrionária, em que se destacava o maestro negro Joaquim José de Mendanha. Ver: Letícia Rosa Marques, "O maestro Joaquim José de Mendanha: música, devoção e mobilidade social na trajetória de um pardo no Brasil oitocentista”, Tese (Doutorado em História) Pontifícia Universidade Católica do Rio Grande do Sul, Porto Alegre, 2017. Felipe Rodrigues Bohrer, “A música na cadência da história: raça, classe e cultura em Porto 
bem como em ações de caráter mutualista. Sabino Antônio Feliciano foi tesoureiro da Sociedade Floresta Aurora em 1882 e talvez também tenha ocupado cargos de direção em outros momentos. ${ }^{7}$ A tesouraria era uma seção-chave na organização de uma sociedade, e o seu titular deveria ser dotado de capital cultural razoável, tanto em termos de cultura letrada como de organização contábil e cálculos matemáticos. Isso sem mencionar a moralidade e a honestidade exigidas do titular, não só tendo como base um comportamento individual irretocável, mas, principalmente, o reconhecimento comunitário dessa integridade. Obviamente, essa integridade englobava também a família de Sabino, já que o julgamento comunitário tinha uma noção extensa dos comportamentos individuais e de seus pertencimentos.

Mas recuemos um pouco no tempo. Costurando várias tipologias documentais podemos nos aventurar a resumir as vicissitudes biográficas deste personagem negro. O primeiro contato que tivemos com Sabino foi através do inventário post mortem e testamento de seu pai. Segundo o seu registro de óbito, o "preto" Antônio José Feliciano era natural da África e "aparentava" ter 70 anos de idade quando morreu de "espasmos", sendo enterrado em 12 de março de 1888, na sepultura 437A do $5^{\circ}$ quadro de entremuros do cemitério da Santa Casa de Misericórdia de Porto Alegre, para onde foi conduzido à mão. ${ }^{8} \mathrm{O}$ pai de Sabino, o açougueiro Antônio José Feliciano, confeccionou testamento em 27 de fevereiro do mesmo ano em que faleceu, já doente:

Alegre no pós-abolição”, Dissertação (Mestrado em História), Universidade Federal do Rio Grande do Sul, Porto Alegre, 2014. Nara Regina Dubois de Jesus, "Clubes sociais negros em Porto Alegre - RS: a análise do processo de recrutamento para a direção das associações Satélite, Prontidão e Floresta Aurora, trajetórias e a questão da identidade racial”, Dissertação (Mestrado em Sociologia) - Universidade Federal do Rio Grande do Sul, Porto Alegre, 2005.

7 Marisa Schneider Nonnenmacher, Tudo começou em uma madrugada: Sociedade Beneficente Cultural Floresta Aurora (1872-2015), Porto Alegre: Medianiz, 2015, p. 41.

8 Arquivo do Centro Histórico Cultural da Santa Casa de Misericórdia de Porto Alegre (CHC/SCMPA), Porto Alegre, livro de óbitos n 18, registro 32895. 
Eu, Antônio José Feliciano, achando-me doente de cama, mas em meu perfeito juízo e claro entendimento, resolvi fazer o meu testamento, para ser cumprido depois de minha morte, e o faço do modo que segue. Sou natural da costa da África, de onde vim para o Brasil no ano de 1846. Declaro que meus pais são falecidos e que sou solteiro, porém tenho filhos naturais, que são - Sabino - filho da Maria Rita; Isidoro, filho de Felicidade; e Maria Antônia, Felicidade, João Antônio e José Maria, filhos de Benedita; e Antônio, filho de Maria, que foi escrava de João Raupp. Sendo todos meus filhos naturais, pelo presente testamento como tais os reconheço e os declaro meus herdeiros. [...] Declaro que há muitos anos vivo com Ana Maria Antônia, e para ela deixo a metade da casa do Alto da Bronze. Desejo que na partilha dos meus bens, sejam mais ou menos observadas estas instruções: a minha vontade, que o meu filho Sabino Antônio Feliciano seja aquinhoado na outra metade da casa do Alto da Bronze, a minha filha Maria Antônia na primeira das minhas casas da rua da Imperatriz, a minha filha Felicidade na outra casa da rua da Imperatriz, o meu filho João Antônio em uma das casas da rua do Tavares, a meu filho José Maria na outra imediata, e os meus filhos Isidoro e Antônio no terreno da rua de Dom Afonso. Desejo que a partilha se aproxime destas minhas instruções o mais que for possível. Quero que meu enterro seja o mais simples possível, e que se reze por minha alma no sétimo dia algumas missas. ${ }^{9}$

Segundo o inventário e testamento do africano Antônio José Feliciano, ele tinha sete filhos vivos com quatro mulheres diferentes. Todos os sete foram beneficiados com legados de seu pai natural. Trataremos mais adiante de dois deles, justamente os mais velhos, Sabino e Isidoro, dos quais obtivemos mais alguns dados. Os restantes nasceram após a lei de 28 de setembro de 1871, sendo, portanto, de ventre livre.

9 Arquivo Público do Estado do Rio Grande do Sul (APERS), Porto Alegre, Juízo de Órfãos de Porto Alegre, $1^{\circ}$ Cartório, auto 2303, inventariante: Sabino Antônio Feliciano, Inventário post-mortem de Antônio José Feliciano, 1888. Destaque do original. 
Segundo as idades mencionadas no testamento acima, em 1873 nasceu Maria Antônia (filha de Benedita), em 1874 Antônio (filho da crioula Maria), em 1876 Felicidade, em 1879 João Antônio e em 1881 José Maria, esses três últimos também filhos de Benedita. ${ }^{10}$

Sabino era o primogênito do africano Antônio José Feliciano, nascido em 11 de julho de 1849, três anos, portanto, depois da chegada de seu pai em Porto Alegre, trazido pela diáspora transatlântica. Confiando em seus filhos mais velhos e tendo-os por perto, o africano Antônio José Feliciano nomeou Sabino como primeiro testamenteiro, Isidoro como segundo e seu amigo Miguel Porto como terceiro. $\mathrm{O}$ africano forro Miguel Porto tinha na época 65 anos e era açougueiro, como seu falecido patrício, o que nos sugere que talvez fossem parceiros nos negócios. Miguel Porto conseguiu a alforria em 27 de fevereiro de 1865, de seu senhor Manuel Ferreira Porto Filho. O açougue de Antônio José Feliciano localizava-se no mercado público de Porto Alegre, e os seus utensílios foram descritos e avaliados no seu inventário: picadeiro, balcão com pedra-mármore, balança com os competentes pesos, dois machados, um serrote, facas e ganchos de ferro em número de 30, tudo avaliado em 50 mil réis. Conforme aparece no inventário, Feliciano tinha cinco imóveis na zona central de Porto Alegre. ${ }^{11}$

Feliciano não era casado legalmente com Ana Maria Antônia, por isso ela não aparece entre os herdeiros legítimos, mas seu amásio

10 Maria conseguiu se alforriar de sua escravizadora, a viúva Angélica da Cunha Raupp, em 21 de janeiro de 1880, gratuitamente. APERS, $1^{\circ}$ Tabelionato de Notas de Porto Alegre, livro de registros diversos $\mathrm{n}^{\circ}$ 25, folha 186v, Carta de alforria de Maria, 21 jan. 1880. O equívoco de Antônio José Feliciano em afirmar que Maria era ex-escrava de João Raupp provavelmente se originou no fato de que este tinha uma sociedade comercial com seu irmão Quintiliano, casado com Angélica. No inventário post mortem de Quintiliano Raupp, em 1867, constava apenas uma escravizada, justamente a crioula Maria, com 15 anos de idade, avaliada em um conto de réis. APERS, $1^{\circ}$ Cartório de Órfãos de Porto Alegre, maço 91, auto 1947, inventariante: Angélica da Cunha Raupp, Inventário de Quintiliano Raupp, 1867.

11 APERS, $1^{\circ}$ Tabelionato de Porto Alegre, Registros Diversos, livro 8, folha 29, Carta de alforria de Miguel, 27 fev. 1865. APERS, $1^{\circ}$ Cartório Cível e Crime, maço 134, auto 3602, Processo-crime, 1873. Não aparecem no inventário dívidas com salários, o que nos faz pressupor que esse açougueiro trabalhava sozinho, ainda que às vezes empregasse um “patrício” para dias de trabalho mais intenso e tarefas específicas. 
a ampara com um legado no testamento. Aliás, acreditamos que o sobrenome Antônia derivasse da perenidade da relação dela com Antônio José Feliciano, ainda que a aliança não fosse oficial. A declaração “quero que meu enterro seja o mais simples possível”, além de demonstração religiosa de humildade, provavelmente também era um registro da percepção deste africano de quanto custava um velório e enterro decente, o que certamente espoliaria a sua herança, diminuindo radicalmente o patrimônio que queria legar aos seus descendentes. Quiçá os patrícios desse africano já estivessem encarregados de lhe prover um enterro decente, aos moldes de suas religiosidades diaspóricas.

O arrolamento das dívidas em um inventário nos permite perceber as redes sociais e mercantis em que o falecido estava envolvido e nos fornece dados sobre o dinamismo das suas atividades laborais. ${ }^{12} \mathrm{~A}$ firma de Souza \& Rangel pediu o ressarcimento de $269 \$ 680$ réis, quantia relativa ao fornecimento de carne para o açougue de Feliciano. No período de 29 de janeiro a 23 de fevereiro de 1888, menos de um mês, foi fornecido um total de 1.774 quilos de carne, a 180 réis por quilo. Já Belchior Vargas de Andrada cobrava 41\$020 réis pelo fornecimento de carne verde, ao mesmo preço por quilo. Por sua vez, Francisco Py reivindicava um valor de 43\$720 réis, proveniente do adiantamento de quantias em três oportunidades: 18 mil réis pelo aluguel do quarto do mercado público, por pedido de Sabino, "para não perder o direito” na Câmara Municipal; $10 \$ 720$ réis por um peso de carne de 67 quilos (26 de fevereiro de 1888) e 15 mil réis emprestado a Sabino, no dia do falecimento de seu pai, para despesas do enterro. ${ }^{13} \mathrm{O}$ patrimônio do africano da costa Feliciano deu conta das

12 Sobre o uso de inventários post mortem, ver: João Luís Fragoso e Roberto Guedes Ferreira, "Alegrias e artimanhas de uma fonte seriada” in Tarcisio Rodrigues Botelho et al., História quantitativa e serial no Brasil: um balanço, São João del-Rei: ANPUH-MG, 2001, pp. 1-25. Luís Augusto Farinatti, “Construção de séries e microanálise: notas sobre o tratamento de fontes para a história social”, Anos 90, v. 15, n. 28 (2008), pp. 57-72.

13 Feliciano havia tratado ainda com Francisco Cândido Lopes a compra de um terreno na rua Castro Alves, em $1^{\circ}$ de setembro de 1885, por 950 mil réis. Deu 100 mil réis de entrada, sendo o restante pago em mensalidades de 50 mil réis mas desde abril de 1886 
dívidas passivas e das demais despesas, restando um monte-menor ${ }^{14}$ de 2:943\$060 réis, ficando a amásia Ana Maria Antônia com a maior fatia (750 réis) e partes iguais de 313\$294 réis divididas de forma igualitária entre os sete filhos naturais do falecido.

Na lista dos cidadãos votantes da Paróquia de Nossa Senhora do Rosário em 1880 há 13 açougueiros qualificados, com rendas entre 200 e 600 mil réis anuais, numa média de 319 mil réis. ${ }^{15}$ Considerando os 1.302 indivíduos dessa lista de 1880 cuja renda foi listada, temos 503 com até 350 mil réis, o que equivale a cerca de $39 \%$ do total de votantes. Assim, podemos pensar os açougueiros como integrantes de uma camada social intermediária de pequenos ou médios negociantes. É normal que, mesmo que tivesse renda, Antônio José Feliciano não aparecesse qualificado, já que era estrangeiro (africano) e teria que se naturalizar para obter a cidadania política. ${ }^{16}$

Em sua pesquisa sobre o abastecimento de alimentos para a cidade de Salvador do final do XVIII a meados do XIX, Richard Graham salienta a "imensa variedade de seus moradores, assim como a sua estreita e multifacetada interconectividade”. ${ }^{17}$ Graham menciona várias categorias sociais e laborais encarregadas de distribuir e vender alimentos - donos de armazéns/tabernas, açougueiros, comerciantes de gado, marujos, mestres de embarcações, quitandeiras - e enfatiza que esses profissionais “estavam ligados a quase todo mundo na cidade”:

parou de pagar as prestações, angariando uma dívida de $249 \$ 600$ réis. Havia também um empréstimo de 100 mil réis (20 de agosto de 1886) com José Gomes de Oliveira.

14 "Monte-menor" é o total líquido do patrimônio avaliado em um inventário, quando descontadas as despesas com funeral, dívidas passivas, pagamento de impostos etc.

15 Arquivo Histórico do Rio Grande do Sul (AHRS), fundo Eleições, Lista Geral dos cidadãos qualificados votantes da Paróquia de Nossa Senhora do Rosário da cidade de Porto Alegre, no ano de 1880, 1880.

16 Maria Odila Leite da Silva Dias, "Sociabilidades sem história: votantes pobres no império, 1824-1881”, in Marcos Cezar de Freitas (org.), Historiografia brasileira em perspectiva, São Paulo: Contexto, 1998, pp. 57-71. Herbert S. Klein, “A participação política no brasil do século XIX: os votantes de São Paulo em 1880”, DADOS, v. 38, n. 3 (1995), pp. 527-544.

17 Richard Graham, Alimentar a cidade: das vendedoras de rua à reforma liberal (Salvador, 1780-1860), São Paulo: Companhia das Letras, 2013, p. 22. 
Pessoas de tipo mediano, algumas mais abastadas do que outras, assim como algumas muito pobres e as escravizadas, todas elas dando duro no trabalho, enchiam a cidade e a faziam funcionar. Esse ambiente urbano permitiu a formação de um grande setor intermediário, ocupado no comércio, com laços tanto verticais como horizontais com outros. ${ }^{18}$

Graham menciona que em Salvador os açougueiros formavam um grupo heterogêneo, mas que parecia se caracterizar, no geral, por uma precária posição social, o que faz com que esse historiador os pense como distantes de algumas obsessões racistas da elite. Graham os pensa assim pois percebe os açougues como "pontos de reunião de escravos à toa, alguns dos quais tinham sido mandados para comprar carne, mas ficavam conversando com outros”. ${ }^{19}$ O médico Raimundo Nina Rodrigues menciona inscrições iorubas islâmicas na fachada de um açougue na Baixa dos Sapateiros, em Salvador, sendo o açougueiro um crioulo. ${ }^{20} \mathrm{Na}$ parede interna do estabelecimento, a inscrição é acompanhada por uma cruz e o título "O alufá”, sacerdote muçulmano em ioruba. Nina Rodrigues chama de "língua nagô" aqueles escritos, dos quais, de tão admirado, tirou uma foto, em 1895.

Como vimos através das dívidas passivas do inventário do africano da costa Feliciano, os açougueiros eram dependentes dos marchantes, que lhes forneciam carne, mesmo que às vezes pudessem adquirir a mercadoria por vias alternativas, já que o abigeato era uma prática costumeira, e ao redor de Porto Alegre muitas propriedades rurais (pequenas e médias, principalmente) poderiam fornecer carne diretamente. Claro que o açougue de Feliciano ficava no mercado público de Porto Alegre, o que tornava esse local estrategicamente localizado tanto do ponto de vista da circulação de consumidores como da chegada de produtos dos fornecedores (o mercado

18 Graham, Alimentar a cidade, 2013, p. 22.

19 Graham, Alimentar a cidade, 2013, p. 191.

20 Raimundo Nina Rodrigues, O animismo fetichista dos negros baianos, Rio de Janeiro: UFRJ; Biblioteca Nacional, 2006, p. 35; Os africanos no Brasil, $7^{\mathrm{a}}$ ed. Brasília, DF: Editora UnB, 1988, pp. 142-143. 
é vizinho ao porto fluvial no lago Guaíba), mas, em contrapartida, também facilmente vigiado pelas autoridades municipais e policiais.

Pelo número de mulheres citadas no testamento, pela citação pormenorizada dos seus nomes e dos filhos tidos com cada uma e a distribuição de patrimônio a cada um (o que significa preocupação com a manutenção dos rebentos), podemos pensar em um arranjo familiar próximo à poligamia, ou pelo menos no investimento em uma família extensa. Não se tratava, evidentemente, de promiscuidade, luxúria ou da hipersexualidade atribuída à raça negra. Não foram relações passageiras e que não deixaram marcas na memória e no afeto, já que os nomes são citados corretamente, tanto das mães quanto dos filhos gerados naqueles encontros afetivo-sexuais, dos quais não temos informações quanto a suas durações e arranjos (coabitação etc.). ${ }^{21}$

Estes arranjos afetivos e familiares extensos do africano da costa Antônio José Feliciano dialogam com seu não desprezível patrimônio material. Destaca-se ainda o fato dele saber o ano exato em que chegou ao Brasil (1846, provavelmente por ser no ano seguinte ao término da guerra civil farroupilha, que durou de 1835 a 1845), nos fazendo cogitar que ele era um expoente naquela comunidade afro-diaspórica. A quantidade de carne fresca que Feliciano adquiriu em menos de um mês - 1.774 quilos - nos dá a dimensão do excelente movimento de seu estabelecimento, localizado em um ponto nodal da capital. Se Graham enfatiza os açougues como um ponto de encontro de escravizados e forros, imaginamos que essa sociabilidade deveria se exacerbar se o açougueiro fosse um africano forro. Devemos aqui lembrar que, segundo o censo de 1872, a maior comunidade de estrangeiros de

21 Lélia Gonzales, "Racismo e sexismo na cultura brasileira”, Revista Ciências Sociais Hoje, v. 4, n. 4 (1984), pp. 223-244. Mariza Corrêa, "Sobre a invenção da mulata”, Cadernos Pagu, v. 7, n. 6 (1996), pp. 35-50. Elisa Larkin Nascimento, O sortilégio da cor: identidade, raça e gênero no Brasil, São Paulo: Selo Negro, 2003. Sueli Carneiro, Racismo, sexismo e desigualdade no Brasil, São Paulo: Selo Negro, 2011. Marcelo Paixão e Flávio Gomes, "Histórias das diferenças e das desigualdades revisitadas: notas sobre gênero, escravidão, raça e pós-emancipação”, Estudos Feministas, v. 16, n. 3 (2008), pp. 949-969. 
Porto Alegre era a de africanos, superando imigrantes portugueses, alemães e oriundos de países platinos. ${ }^{22}$ Tudo isso nos faz cogitar que atividade laboral e etnicidade confluíam naquele açougue do mercado público. Assim, pensamos o açougueiro Antônio José Feliciano como um mediador cultural ou, quem sabe, uma liderança étnico-religiosa daquela comunidade diaspórica meridional.

O africano da costa Antônio José Feliciano aparece em tipologias documentais diversas, mostrando como estava interconectado com outras pessoas semelhantes a ele. $\mathrm{O}$ crioulo Isidoro, com 8 anos de idade, obteve a liberdade através de um documento passado por sua escravizadora, Maria Mônica de Azevedo, em 13 de maio de 1874. A carta foi registrada no cartório local no mesmo dia em que foi redigida, procurando seus familiares com isso diminuir os riscos da precarização da liberdade vigente no Brasil escravista. ${ }^{23} \mathrm{~A}$ alforria foi obtida através do pagamento de 500 mil réis, quantia alta, principalmente para grupos populares, como podemos ver pelos valores constantes no inventário aqui já descrito. Pois foi justamente o inventariado, o açougueiro da costa Feliciano, quem deu a quantia necessária para indenizar a senhora Mônica e, assim, libertar o seu filho Isidoro, filho de Felicidade, a quem no testamento de 1888 indicou como segundo testamenteiro. ${ }^{24}$

Ainda persistia o conflito com o Paraguai quando uma outra escritura de liberdade mencionou Antônio José Feliciano. Em 25 de março de 1868 foi libertada do cativeiro a menina Joana, então com 12 anos de idade, filha da crioula já falecida Frutuosa, escravizada

22 Paulo Roberto Staudt Moreira, "Uma africandade de parentes: forros, diásporas africanas e comunidades afrodiaspóricas no Brasil meridional (Porto Alegre, século XIX)” in Eduardo Neumann e Carla Brandalise (org.), O Rio Grande do Sul revisitado: novos capítulos, Porto Alegre: Editora Martins Livreiro, 2019, pp. 56-82.

23 Sidney Chalhoub, "Precariedade estrutural: o problema da liberdade no Brasil escravista (século XIX)”, Revista de História Social, n. 19 (2010), pp. 33-62.

24 APERS, $1^{\circ}$ Tabelionato de Porto Alegre, Livro de Registros Diversos $n^{\circ} 22$, folha 149 , Carta de alforria de Isidoro. 
pelo comendador Joaquim de Paiva Freire de Andrade e sua mulher. ${ }^{25}$ A carta foi concedida mediante o pagamento da avultada quantia de 1.600 réis pelo pai de Joana, o preto forro Gregório Ferreira, auxiliado no acúmulo desse pecúlio pelos padrinhos da menina, Antônio José Feliciano e Bernarda de Castro. Os senhores tiveram ainda o atrevimento de deixar impresso que a carta fora concedida em retribuição à amizade e por ser "nossa cria, nascida em nossa casa e criada com muita estima entre nossos filhos”. ${ }^{26}$

Gregório Ferreira era africano nagô e teve que desembolsar a mesma quantia (1.600 réis) para conseguir a sua própria liberdade, por carta de alforria de $1^{\circ}$ de março de 1860, passada pelo escravizador José Antônio Rodrigues Ferreira e registrada em cartório no dia imediato. ${ }^{27}$ Morta a crioula Frutuosa, Gregório encetou uma relação afetiva com a preta Felicidade Mendes Ribeiro, também nagô. Os dois se casaram em 1877 e em sua habilitação matrimonial pediram dispensa de apresentar as certidões de batismo, pois receberam os santos óleos do catolicismo na Bahia, ponto brasileiro onde aportaram da diáspora transatlântica. A nagô Felicidade, em sua vida de liberta, assumiu o sobrenome senhorial, talvez como um esquema de localização social, já que teve que ressarcir

25 Inácio Joaquim de Paiva Freire de Andrade nasceu em Porto Alegre em 1811, filho do cirurgião-mor Inácio Joaquim de Paiva e Maria Águeda de Paiva. Foi deputado provincial entre os anos de 1846 e 1847. Ver Sérgio da Costa Franco, "Gaúchos na Academia de Direito de São Paulo no século XIX”, Revista Justiça \& História, v. 1, n. 1-2 (2001), pp. 107-129.

26 APERS, $1^{\circ}$ Tabelionato de Porto Alegre, Livro de Registros Diversos $n^{\circ} 19$, folha $114 \mathrm{v}$, Carta de alforria de Joana. Segundo Gabriel Aladrén, "fica evidente que nas cartas de alforria os desejos e interesses daqueles que estão sendo libertados, os escravos, praticamente não aparecem e, em casos raros, é possível vislumbrá-los nas entrelinhas do discurso senhorial” (Gabriel Aladrén, "Liberdades negras nas paragens do Sul: alforria e inserção social de libertos em Porto Alegre, 1800-1835”, Dissertação (Mestrado em História), Universidade Federal Fluminense, Niterói, 2008, p. 29). Joana nasceu em 26 de novembro de 1856 e foi batizada na Igreja do Rosário de Porto Alegre, em 6 de janeiro de 1857. Era filha natural de Frutuosa e os padrinhos foram os pardos forros Antônio José Feliciano e Bernarda Isabel. Arquivo Histórico da Cúria Metropolitana de Porto Alegre (AHCMPA), Livro $1^{\circ}$ de Batismos de Escravos da Paróquia de Nossa Senhora do Rosário, folha 230.

27 APERS, $1^{\circ}$ Tabelionato de Notas de Porto Alegre, Livro de Registros Diversos $\mathrm{n}^{\circ} 16$, folha 132, Carta de alforria de Gregório. 
o seu senhor Joaquim José Mendes Ribeiro com um conto e 400 mil réis, em 31 de janeiro de $1857 .{ }^{28}$ A preta mina Felicidade avisou as autoridades em 24 de junho de 1890 de que seu esposo Gregório falecera e atuou como sua inventariante. ${ }^{29}$ No testamento feito por ambos, eles se identificaram como da costa da África, tendo por volta de 64 anos de idade. O patrimônio desse casal de africanos era surpreendente, chegando a um monte-menor de 25:914\$593 réis.

Mesmo que estas informações sobre o nagô ou mina Gregório Ferreira pareçam, neste momento, um despropositado desvio do tema do artigo, mais adiante elas nos servirão para endossar alguns argumentos. Assim, citaremos brevemente apenas mais dois documentos que nos ajudam a perceber as redes sociais e étnicas que vicejavam naquelas comunidades afro-diaspóricas sul-rio-grandenses.

Os inventários post mortem, normalmente tratados como fontes quantitativas, nos fornecem pistas imprescindíveis para visibilizar e entender o funcionamento de determinadas redes sociais. Durante o inventário do africano nagô Gregório Ferreira, apresentou-se o preto africano Antônio Fernandes dizendo que um dos imóveis listados como patrimônio do falecido na verdade era seu. Fernandes explicou que morou muitos anos na rua da Alegria, hoje General Vitorino, $\mathrm{n}^{\circ} 70$, e finalmente tratou de comprar aquele terreno, para nele edificar uma casa. Pediu então a quantia necessária para o seu patrício Gregório Ferreira, que lhe disponibilizou 2.800 réis, “estando aí incluído o necessário para sisa e mais gastos”. O terreno foi comprado em 13 de março de 1884 e ali Fernandes construiu uma casa e, apesar de pontualmente pagar a dívida em parcelas mensais, ficou sabendo que o terreno estava erroneamente em nome de seu patrício.

28 AHCMPA, $\mathrm{n}^{\circ}$ 129, caixa 290, Habilitação matrimonial de Gregório e Felicidade, 1877. APERS, $2^{\circ}$ Tabelionato de Porto Alegre, livro 16, folha 221v, Carta de alforria de Felicidade, 5 fev. 1857.

29 APERS, Cartório da Provedoria de Porto Alegre, inventário $\mathrm{n}^{\circ}$ 735, maço 43, Inventário de Gregório Ferreira, 1891. 
Às 9 horas do dia 9 de abril de 1891 faleceu o africano da costa Antônio Bittencourt, com 60 anos de idade. ${ }^{30}$ Ele trabalhava como pedreiro e obteve a alforria em 1864, quando foi descrito como nagô e teve que pagar um conto e 600 mil réis a seu senhor Francisco Antônio da Silva Bitttencourt. ${ }^{31} \mathrm{O}$ precavido nagô Antônio Bittencourt lavrou seu testamento em 26 de julho de 1874, delegando a sua escrita a Joaquim Ribeiro Pinto. No documento, disse que era preto e liberto, solteiro, da costa da África, sendo seus pais falecidos e não tendo filhos - "não tenho ascendentes nem descendentes”. Disse ainda que era católico - "em cuja fé nasci, criei-me, tenho vivido e protesto morrer" - sendo essa expressão-padrão provavelmente inserida pelo escrevente..$^{32} \mathrm{O}$ testamento, após a morte de Antônio, foi apresentado para as autoridades pelo africano nagô Gregório Ferreira, nomeado pelo falecido como seu primeiro testamenteiro:

Declaro que deixo aos meus amigos, os pretos libertos Samuel de Lima e Gregório Ferreira, a minha casa número 160, a rua do Coronel Fernando Machado, nesta cidade, de porta e janela na frente, com os fundos ao norte a meia quadra, e o terreno ao lado, tendo a casa e terreno 53 palmos de frente - aos quais instituo por meus únicos e universais herdeiros de todos os meus bens que existirem ao meu falecimento. ${ }^{33}$

Caso Gregório não pudesse ou não quisesse se encarregar de seu inventário, Antônio indicava como seu segundo testamenteiro o africano

30 CHC/SCMPA, Livro de Óbitos de Pessoas Livres n ${ }^{\circ}$ 19, registro 38183, Óbito de Antônio Bittencourt, enterrado em 09/04/1891, sepultura 92A do $6^{\circ}$ quadro de entremuros, conduzido à mão, 1891.

31 APERS, $1^{\circ}$ Tabelionato de Porto Alegre, Registros Diversos n ${ }^{\circ} 18$, folha 18, Carta de alforria de Antônio, 7 dez. 1864.

32 Joaquim Ribeiro Pinto foi testemunha em um processo-crime de 1866, quando declarou ser branco, solteiro, natural do Espírito Santo, morador em Porto Alegre e que trabalhava de escrevente (APERS, Cartório Sumário Júri de Porto Alegre, maço 36, processo 1087).

33 APERS, Cartório da Provedoria de Porto Alegre, maço 73, auto 2310, Testamento de Antônio Bittencourt. 
mina Samuel Lima, que aos 40 anos de idade, em 1867, obteve alforria pagando um conto e 600 mil réis a Ernestina de Souza Lima. ${ }^{34} \mathrm{Na}$ falta de parentes consanguíneos, o africano da costa/nagô recompensava seus amigos e parentes étnicos Gregório e Samuel. Sendo todos já de avançada idade, certamente tinham muitas experiências em comum, um patrimônio étnico-linguístico compartilhado e deviam ajudar uns aos outros na comum ancianidade. ${ }^{35}$

Voltando a Sabino Antônio Feliciano, ele faleceu em 11 de setembro de 1898, em Porto Alegre, sem deixar testamento e filhos. ${ }^{36}$ A inventariante foi sua viúva, Joana Ferreira da Conceição, e ele deixou, além de ações da Cia. Hidráulica Guaibense, seis imóveis, mostrando que seguia a mesma via de investimento de seu pai. Pelo menos um destes imóveis (na rua Fernando Machado, $n^{\circ}$ 162) era "composto de diversos cortiços”, o que evidencia como membros da elite negra local também encontravam vantagem no crescimento demográfico de Porto Alegre no final do século. Por outro lado, lembremos a clássica expressão do historiador Sidney Chalhoub, que mencionava que o crescente número de indivíduos não brancos nos espaços urbanos configurou a criação de “cidades negras”, com espaços de solidariedades diversos. Além dos territórios negros já conhecidos (Colônia Africana,

34 APERS, $1^{\circ}$ Tabelionato de Porto Alegre, Registros Diversos n ${ }^{\circ}$ 18, folha 252, Carta de alforria de Samuel, 7 mar. 1867.

35 O africano da costa Samuel Lima morreu em 14 de abril de 1885 em sua casa na rua General Paranhos (antiga do Poço), no centro de Porto Alegre. Ele indicou os africanos Antônio de Bittencourt e Gregório Ferreira como testamenteiros e deixou o usufruto de sua casa para a sua companheira, também africana, Carlota José Pinto Gomes. Carlota pagou 1:850\$ réis para o seu escravizador José Pinto Gomes e este redigiu uma escritura outorgando-lhe liberdade em 30 de julho de 1858. Em 8 de março de 1895, com 78 anos de idade, faleceu Carlota, de arteriosclerose. APERS, Cartório da Provedoria de Porto Alegre, maço 38, auto 648, inventariante: Antônio Bittencourt, Inventário de Samuel de Lima, 188. APERS, $1^{\circ}$ Tabelionato de Notas de Porto Alegre, Registros Diversos n 16 , folha 9v, Escritura de liberdade de Carlota, 30 jul. 1858.

36 APERS, $2^{\circ}$ Cartório Civil de Porto Alegre, auto $n^{\circ}$ 644, maço 19, inventariante: Joana Ferreira da Conceição, Inventário post mortem de Sabino Antônio Feliciano, 1898. 
Arraial da Baronesa etc.), ${ }^{37}$ algumas residências assumiam um papel de quilombos urbanos, amalgamando sociabilidades diversas.

A viúva e inventariante de Sabino, Joana Ferreira da Conceição, nasceu na então província de São Pedro do Rio Grande do Sul. Após a morte de Sabino, ela contraiu segundas núpcias com outro integrante da Sociedade Floresta Aurora, Miguel Arcanjo da Cunha. ${ }^{38} \mathrm{O}$ que contaremos a seguir nos induz a considerá-la íntegra e honesta, mas também que ela sabia a importância para o marido das suas relações familiares, e assim conduziu o inventário post mortem de uma maneira ao gosto de Sabino, mas que lhe diminuiu bastante a herança recebida.

\section{Maria Rita, Mina Nagô}

O inventário post mortem de Sabino sofre uma guinada que muito nos beneficiou. Sua viúva Joana Ferreira da Conceição informou ao juiz que, "no meio de papéis pertencentes ao seu marido, foi encontrada uma carta, pela qual se verifica que tem esse mãe viva na cidade da Bahia, capital do estado do mesmo nome". A viúva passou a "colher informações" e a partir delas construiu a certeza de que a preta mina Maria Rita, mãe de Sabino (conforme indicava o testamento de seu pai Antônio José Feliciano),

37 Sobre os territórios negros de Porto Alegre, ver: Eduardo Kersting, "Negros e a modernidade urbana: a colônia africana de Porto Alegre (1880-1920)”, Dissertação (Mestrado em História), Universidade Federal do Rio Grande do Sul, Porto Alegre, 1998. Marcus Vinicius de Freitas Rosa, Além da invisibilidade: história social do racismo em Porto Alegre durante o pós-abolição, Porto Alegre: EST Edições, 2019. Daniele Machado Vieira, “Territórios negros em Porto Alegre/RS (1800-1970): geografia histórica da presença negra no espaço urbano”, Dissertação (Mestrado em Geografia), Universidade Federal do Rio Grande do Sul, Porto Alegre, 2017. Jane Rocha de Mattos. “Que arraial que nada, aquilo lá é um areal”: o Areal da Baronesa: imaginário e história (1879-1921)”, Dissertação (Mestrado em História) - Pontifícia Universidade Católica do Rio Grande do Sul, Porto Alegre, 2000.

38 Paulo Roberto Staudt Moreira, “'Miguel Archanjo da Cunha já não existe’: o associativismo da Sociedade Beneficente Floresta Aurora e as vicissitudes biográficas de um barbeiro negro, liberal e católico”, Revista de História Regional, v. 24, n. 2 (2019), pp. 252-281. 
lá morava. Joana tinha boas condições para coletar informações a respeito daquela africana nagô, que talvez ainda vivesse na Bahia. Ela conhecia intimamente a comunidade afro-diaspórica local, na qual foi gestada, e se informações ou boatos corriam, ela teria como colhê-los.

Joana, viúva de Sabino, já apareceu nesse artigo. Ela foi alforriada pelo pai, o nagô Gregório Ferreira, e por seus padrinhos, os pretos forros Antônio José Feliciano e Bernarda Isabel (ou de Castro), em 1868. Quando pensamos em comunidades afro-diaspóricas, não podemos esquecer os filhos desses ventres africanos, que viveram sob a influência cultural direta de seus progenitores (isso, claro, se a família não foi separada por mortes ou vendas). Quando Joana desposou Sabino na Capela do Menino Deus, em 29 de setembro de 1877, o laço entre os noivos não foi o único a se afirmar, mas também foram consolidados e reatualizados aqueles que uniam os africanos Gregório (pai da noiva) e José (pai do noivo), que já eram compadres antes desse enlace matrimonial. ${ }^{39}$ Com o entrecruzamento dessas trajetórias, podemos constatar que:

Na diáspora, enfim, instituições como o parentesco - fosse por afinidade (cunhados, sogros, genro/nora) ou espiritual (padrinhos e afilhados, compadres/comadres) - não só possibilitaram aos africanos reorganizar famílias na experiência de escravidão e de liberdade, mas, sobretudo, fizeram com que deixassem de ser meros aglomerados de gente para se tornar membros de determinadas comunidades - irmandades, espaços de trabalho, vizinhança, onde teciam malhas de solidariedade. Isto é, o parentesco para [essas] pessoas [...] seria o mesmo que viver numa comunidade cujas raízes foram firmemente plantadas no Novo Mundo. Essas relações comunitárias eram pautadas por relações interpessoais que definiam o papel de cada indivíduo no grupo e na sociedade. ${ }^{40}$

39 AHCMPA, auto 134, caixa 290, Habilitação de Casamento de Sabino Antônio Feliciano \& Joana Maria da Conceição, 1877.

40 Valéria Gomes Costa, “Trajetórias negras: os libertos da Costa d’África no Recife (18461890)”, Tese (Doutorado em História), Universidade Federal da Bahia, Salvador, 2013. 
Na sequência, Joana insere no inventário de seu esposo uma carta de sua mãe, Maria Rita, escrita e assinada numa letra muito bonita. A missiva era uma resposta a Sabino, quando este perguntava se ela não queria vir de Salvador para Porto Alegre. Maria Rita rejeita carinhosamente o convite, dizendo que se ele mandasse 300 ou 400 mil réis ela iria, porque do contrário não teria recursos para o deslocamento. Essa carta evidenciava que a mãe de Sabino estava viva, morando em Salvador, ao menos em 1892, data da carta em que ela, ao final, abençoava o filho.

Meu querido filho.

Inefável a satisfação que terei se estas mal dirigidas linhas forem te encontrar no gozo da mais perfeita saúde, a par de todos que lhe são caros. $\mathrm{Eu}$ ao fazer desta fico com saúde graças a Deus. Recebi a sua carta e fico ciente de tudo quanto nela vem me narrando, porém, agora não é possível satisfazer a sua vontade, pois bem sabe que viagem não se pode fazer sem dinheiro, se deseja de coração que eu vá para junto de si, mande-me trazer a quantia de $300 \$$ réis ou $400 \$$ réis para eu fazer o que é preciso para poder ir, logo que venha o dinheiro irei, sem o que não posso ir, se tivesse vindo nessa última carta, eu ia com o portador quando fosse, mas sem embargo disto, mande o dinheiro que outra qualquer pessoa que para lá for eu irei na companhia. Se no caso de não poder mandar trazer o dinheiro, não mande mais falar em eu ir para lá, porque não posso ir com palavras, como você mesmo deve saber. No mais Adeus, aceite a benção e um apertado abraço de sua carinhosa Mãe. [Assinado] Maria Rita Bahia, 16 de agosto de 1892.

É difícil, por uma pequena missiva como esta, perscrutar o ânimo da remetente ao escrevê-la ou ditá-la. Já havia mais de quatro anos que o pai de Sabino e ex-amásio ou companheiro de Maria Rita morrera em Porto Alegre. Supomos que a correspondência de Sabino teve a finalidade de atualizar sua mãe sobre como ele estava passando, mas também de convencê-la a vir para o Rio Grande do Sul. Apesar de afirmar que estava com “saúde, graças a Deus”, Maria Rita já devia estar com uma idade avançada, 
e Sabino certamente queria ajudá-la em sua velhice, trazendo-a para perto de si. Não sabemos como se estruturou a relação entre os africanos Maria Rita e Antônio José Feliciano; sabemos que eles não sacramentaram sua união na Igreja, mas tiverem um filho "natural”, Sabino.

A carta pode ter sido escrita para Maria Rita por outra pessoa. A carta é bem escrita e com um vocabulário diversificado, mas nada impede que uma quitandeira africana que trabalhava numa cidade como Salvador, um dos maiores portos atlânticos do mundo, absorvesse a cultura letrada. O que nos parece óbvio, olhando o documento manuscrito inserido naquele inventário post mortem, é que quem escreveu a carta ou bilhete também assinou ao final, pois a grafia é a mesma. Se houve delegação de escrita (que pode muito bem ter ocorrido), o protocolo seria que o redator assinasse "a rogo de Maria Rita” ao final. Claro que a informalidade da missiva pode ter feito o redator prescindir desses protocolos de redação. ${ }^{41}$

Já há pesquisas voltadas para as "práticas culturais letradas e leitoras” dos escravizados e forros do século XIX que evidenciam os complexos contatos destes agentes com as práticas escriturárias, sendo que "a impossibilidade de leitura não faz do personagem um não letrado”. ${ }^{42}$ Maria Cristina Wissenbach destaca que o nosso pouco conhecimento sobre essas práticas decorre do uso sistemático que os historiadores fizeram - com ótimos resultados - de "documentos comprometidos com a visão de mundo das classes dominantes”, incluídos aí os produzidos pelos órgãos responsáveis pelo controle social. Para ela, as "artes da escrita”

41 Sobre delegação de escrita, ver: Rodrigo Weimer, “A gente da Felisberta: consciência histórica, história e memória de uma família negra no litoral riograndense no pós-emancipação (c. 1847 - tempo presente)”, Tese (Doutorado em História), Universidade Federal Fluminense, Niterói, 2013.

42 Marialva Barbosa, Escravos e o mundo da comunicação: oralidade, leitura e escrita no século XIX, Rio de Janeiro: Mauad X, 2016, p. 14. Ver também: Alexandra Lima da Silva, "Flores de ébano: a educação em trajetórias de escravizadas e libertas", Revista Brasileira de Pesquisa (Auto)Biográfica, v. 4, n. 10 (2019), pp. 299-311; “O saber que se anuncia: o poder da palavra em tempos de escravidão (Rio de Janeiro, 1830 a 1888)”, Revista Brasileira de História da Educação, v. 18 (2018), p. 1-29. 
relacionavam-se no Oitocentos “às sociabilidades existentes no mundo das cidades, entretidas entre escravos, forros, negros nascidos livres, brancos pobres". ${ }^{43}$ As habilidades que apontamos nesse artigo como necessárias ao desempenho das atividades laborais das quitandeiras mostra como o mundo prático em que elas atuavam era fecundo em termos de transmissão de saberes, entre eles princípios de matemática e leitura.

A romancista, professora universitária e ganhadora do prêmio Nobel de Literatura Toni Morrison, certamente baseada em memórias familiares, destaca em seu livro Voltar pra casa as habilidades de algumas mulheres iletradas: “Algumas precisavam que alguém lesse os versículos da Bíblia para elas porque não conseguiam decifrar sozinhas as letras, então haviam desenvolvido as habilidades dos iletrados: memória perfeita, mente fotográfica, agudo sentido do olfato e da audição”. ${ }^{44}$ Quer dizer, mesmo que tenha havido delegação de escrita por parte de Maria Rita, ali estão impressas as sensações daquela africana, numa escrita que comporta reflexos dos afetos que ela tinha por seu filho. Por isso, cabe a ela a autoria daquele bilhete que descreve sensibilidades familiares entre dois indivíduos (mãe africana e filho crioulo), cujos destinos mesclaram períodos de intensa intimidade e proximidade (da gestação até a maioridade) e de distanciamento geográfico, quando uma nova desterritorialização afastou Sabino de sua progenitora e o reaproximou do pai.

Considerando o bilhete da africana Maria Rita a seu filho Sabino, é interessante pensar nos vínculos entre oralidade e escrita. Segundo Marialva Barbosa, existe uma

relação estreita entre escrita e voz. Os traços das maneiras de dizer aparecem claramente nos escritos, o que faz que só possamos hoje decifrar o que ali foi postado se lermos novamente em voz alta o texto

43 Maria Cristina Cortez Wissenbach, “Cartas, procurações, escapulários e patuás: os múltiplos significados da escrita entre escravos e forros na sociedade oitocentista brasileira”, Revista Brasileira de História da Educação, n. 4 (2002), p. 113.

44 Toni Morrison, Voltar para casa, São Paulo, Companhia das Letras, 2016, p. 119. 
produzido. A voz de quem construiu a escrita continua ecoando na possibilidade interpretativa dos textos no futuro. ${ }^{45}$

Na escolha do vocabulário, na composição das frases, no encadeamento das vírgulas e dos pontos, existe uma espécie de ritmo, entre brusco e ameno, que aproxima mãe e filho. Podemos imaginar quantas vezes aquele objeto de afeto foi lido por Sabino nos anos que antecederam sua morte, talvez em voz alta, procurando rememorar a presença materna. "O corpo conecta com o papel apenas pela mão, mas os índices da voz continuam ecoando através da escrita”, portanto, escrevendo ou ditando, aquela africana forra era a "autora da carta". ${ }^{46}$

De qualquer maneira, naquele papel manuscrito encontramos apego e ternura entre uma mãe e seu filho, que provavelmente não se viam (como veremos adiante) havia cerca de 27 anos. É óbvio que nas relações humanas, principalmente entre pessoas que gozam (ou gozaram) de muita intimidade, a afetividade pode dialogar com a mágoa, sendo a distância e a saudade elementos de potencial tensão e desgaste. Principalmente se considerarmos que Maria Rita já havia passado pelo irrecuperável trauma da diáspora transatlântica, e que muito deve ter sentido o afastamento do filho. Segundo Homi Bhabha, "relembrar nunca é um ato tranquilo de introspecção ou retrospecção. É um doloroso re-lembrar uma reagregação do passado desmembrado para compreender o trauma do passado". ${ }^{47}$

Por não se saber o endereço correto de Maria Rita, e mesmo se ela ainda continuava viva - “o que não é muito certo, visto como desde 1892 para cá nunca mais se dirigiu ela ao mesmo seu filho”, ${ }^{48}$ foi nomeado um curador que a representasse, e o inventário seguiu o seu curso normal. Foi arrolado um monte-mor de 43:779\$350 réis, sendo a meação para a

45 Barbosa, Escravos e o mundo da comunicação, p. 97

46 Barbosa, Escravos e o mundo da comunicação, p. 103.

47 Homi Bhabha, O local da cultura, Belo Horizonte: Editora UFMG, 1998, p. 101.

48 APERS, $2^{\circ}$ Cartório Civil de Porto Alegre, auto $n^{\circ}$ 644, maço 19, inventariante: Joana Ferreira da Conceição, Inventário post mortem de Sabino Antônio Feliciano, 1898. 
viúva e a da mãe de Sabino de não pequena monta, somando 16:627\$715 réis para cada uma. Foi quando, em 29 de setembro de 1900, Maria Rita reapareceu, cobrando lá de Salvador a parte que lhe cabia da herança do filho e acrescentando documentos fundamentais para garantir o seu direito materno (e também para o adensamento de nossa pesquisa).

Pelo menos dois momentos nos permitem perceber as ligações entre estes indivíduos, divididos por milhares de quilômetros, entre Porto Alegre e Salvador. Primeiro, o momento do contato de Sabino com a mãe, que demonstra que ele sabia como achá-la. Por ter morado anos com a mãe e com a senhora de ambos, ele tinha noção de onde residiam e quais eram os contatos a serem acionados para que uma correspondência chegasse às mãos de sua progenitora. Já muitos anos depois, no início de um novo século, Maria Rita conseguiu manter-se informada do desenrolar do inventário de Sabino. Na verdade, ela deve ter sentido a lástima da morte do filho e, em seguida, acionou contatos para comprovar ser sua herdeira legítima. Talvez africanos envolvidos no comércio e na navegação lhe tenham ajudado a obter informações.

Representada em Porto Alegre pelo escritório do advogado Leopoldo Bruck, Maria Rita apresentou dois documentos. O primeiro foi um recibo de pagamento do imposto da meia sisa, datado de 28 de junho de 1847. Esse imposto foi criado pelo alvará de 3 de junho de 1809 e deveria ser pago pela transação mercantil da compra ou venda de escravizados. A meia sisa foi paga por Felisberta Maria da Conceição ao comprar a cativa Maria Rita, descrita como de nação nagô, por 650 mil réis, pertencente a Joaquim José Mendes Ribeiro. ${ }^{49}$

$\mathrm{O}$ segundo documento enviado por Maria Rita, e que deveria fazer parte de seu acervo pessoal, foi um registro de batismo. Comprada em 1847

49 Leopoldo Bruck também atravessou o Atlântico, mas em condições bem melhores do que Maria Rita. Nascido na Alemanha, em 1900 ele tinha cerca de 60 anos de idade e era casado com Maria Albertina. Leopoldo faleceu em 12 de abril de 1906, legando dois imóveis a seus 6 filhos e à viúva. APERS, Cartório da Provedoria, maço 38, auto 41, inventariante: Maria Albertina Bruck, Inventário de Leopoldo Bruck, 1906. APERS, Habilitação de casamento de Leopoldo Bruck \& Maria Albertina Granowsky, 1892. 
pela forra Felisberta, dois anos depois, em 15 de julho de 1849, Maria Rita levou à Igreja Matriz de Porto Alegre, consagrada à Madre de Deus, seu rebento Sabino, para receber os santos óleos de introdução na religião católica. ${ }^{50}$ Ali ele consta como nascido a 11 do mesmo mês, filho natural da africana Maria, escravizada de Felisberta Maria da Conceição, apadrinhado por Antônio, escravizado do doutor Manoel José de Freitas Travassos e amadrinhado por Marcolina Maria da Conceição, crioula liberta. Não encontramos o batismo de Maria Rita, que pode muito bem ter ocorrido na Bahia, como no caso dos nagôs Gregório e Felicidade. ${ }^{51}$ Como o Rio Grande do Sul praticamente não recebia africanos escravizados diretamente da África, Maria Rita deve ter passado por outro lugar do Império antes de ser, através do tráfico interprovincial, desterritorializada para o Brasil meridional, e sabemos a conexão privilegiada que a província da Bahia tinha com a costa da mina e com o Rio Grande do Sul. ${ }^{52}$

Estes documentos são acompanhados por um requerimento de Maria Rita, em que se apresenta como preta africana, mina, moradora em Salvador, na freguesia de Santana, na rua do Gravatá. O requerimento informa que em 1850 Maria Rita se mudou, na companhia de sua senhora Felisberta, de Porto Alegre para Salvador, de onde nunca mais saiu, e que quando era

50 AHCMPA, Livro 6 ${ }^{\circ}$ de Batizados de Escravos da Paróquia da Madre de Deus de Porto Alegre, folha 290v, Registro de batismo de Sabino.

51 Encontramos o documento de batizado de uma preta africana Maria, escravizada por Joaquim José Mendes Ribeiro, na catedral de Porto Alegre, em 20 de janeiro de 1834, a qual deu à luz um menino em 22 de dezembro de 1837, batizado com o nome de Constâncio. Achamos, no entanto, que essa é uma data muito recuada para que essa Maria seja a mãe de Sabino. AHCMPA, Livro $4^{\circ}$ de Batismos de Escravos da Paróquia da Nossa Madre de Deus de Porto Alegre, folha 78v, Batismo de Maria. AHCMPA, Livro $5^{\circ}$ de Batismos de Escravos da Paróquia da Nossa Madre de Deus de Porto Alegre, folha 15, Batismo de Constâncio.

52 Gabriel dos Santos Berute, "Dos escravos que partem para os portos do sul: características do tráfico negreiro do Rio Grande de São Pedro do Sul, c.1790-c.1825”, Dissertação (Mestrado em História), Universidade Federal do Rio Grande do Sul, Porto Alegre, 2006. João José Reis, Flávio dos Santos Gomes e Marcus J. M. de Carvalho, O alufá rufino: tráfico, escravidão e liberdade no atlântico negro (1822-1853), São Paulo: Companhia das Letras, 2010. Marcus J. M. de Carvalho, “O patacho Providência, um navio negreiro: política, justiça e redes depois da lei antitráfico de 1831”, Varia História, v. 30, n. 54 (2014), pp. 777-806. Ricardo Tadeu Caíres Silva, "Memórias do tráfico ilegal de escravos nas ações de liberdade”, Afro-Ásia, n. 35 (2007), pp. 37-81. 
"muito moça” teve um filho de nome Sabino, o qual, "como escravo que era, veio na mesma ocasião, na companhia da justificante e de sua ex-senhora" para a Bahia. Maria Rita diz que nunca casou e sempre em Salvador atuou como quitandeira. O filho, já crescido e aprendiz de pedreiro, foi alforriado por seu pai natural Antônio José Feliciano, açougueiro morador em Porto Alegre, para onde Sabino retornou, não mais voltando.

Eu abaixo assinado, entre os bens que possuo, tenho um escravo crioulo de nome Sabino, de quinze anos, filho de minha escrava Maria Rita, ao qual por meio deste, concedo a liberdade pela quantia de 1 conto e duzentos mil réis, que recebi ao passar desta, do senhor João Luiz de Abreu Silva Júnior, por ordem do pai do mesmo crioulo Sabino, o qual de ora em diante poderá gozar de sua liberdade, como se de ventre livre nascesse, e rogo as justiças de S. M. S e C. o garantam na mesma liberdade. Bahia, 7 de julho de 1865, a rogo de Felisberta Maria da Conceição, por não saber ler nem escrever, Adolfo Diniz Gonçalves. Duas Testemunhas: Constâncio Gracindo de Souza Brito, José Borges Campos. Reconheço as firmas supra. Bahia, 11 de julho de 1865. Em testemunho de verdade. (estava o sinal público) Manoel Jorge Ferreira - Número 101 (sinal) A-duzentos. Pagou duzentos réis. Bahia, 10 de julho de 1865. Seixas. E trasladada da própria conferi, subscrevi e concertei com outro companheiro na Bahia, aos 11 de julho de 1865. Eu Manoel Jorge Ferreira. ${ }^{53}$

Os recursos para a alforria de Sabino foram fornecidos por seu pai. Liberto, Sabino pegou uma embarcação e voltou para a cidade onde nasceu. O senhor que entregou a quantia à senhora Felisberta, "por ordem do pai do mesmo crioulo Sabino”, era parente de outro baiano que se repatriou de Salvador para a província sulina. João Luiz de Abreu Silva

53 Arquivo Público do Estado da Bahia (APEB), Salvador, Livro de Notas do Tabelião, v. 385a , fl. 15v, Escritura de liberdade do crioulo Sabino, 11 jul. 1865. Agradeço a gentileza de sempre do professor Dr. João José Reis, da Universidade Federal da Bahia. 
nasceu na Bahia em 28 de abril de 1808 e assentou praça no Exército na mesma província, em 22 de outubro de 1822. Foi ajudante de campo do coronel Felisberto Gomes Caldeira, comandante da $2^{\mathrm{a}}$ Divisão do Exército Pacificador da Província da Bahia, e em 1833 foi para a província de São Pedro do Rio Grande do Sul, onde empregou-se como vice-diretor do Arsenal de Guerra, localizado na capital. João Luiz atuou ao lado do Império durante toda a guerra civil farroupilha, ${ }^{54}$ casou-se com Antônia Carolina de Lima Abreu e Silva e, em 1852, foi comandante do Corpo Policial da província. Ele morreu em 10 de outubro de 1866, com 64 anos, em Porto Alegre, de hidropericardite, sendo descrito como de cor branca e coronel reformado do Exército. ${ }^{55}$

O portador do dinheiro da alforria de Sabino também havia nascido na Bahia, mas se mudou para Porto Alegre com o deslocamento de seu pai, João Luiz, a serviço do Exército, e de sua mãe, dona Leonor de Betancurt Berenguer Cesar. Ele casou em 16 de outubro de 1852 na Igreja Madre de Deus de Porto Alegre, com dona Leonor Júlia de Saldanha Macedo, ${ }^{56}$ e deve ter voltado (provisória ou permanentemente), por motivos por nós desconhecidos, para a sua província natal.

Esta digressão sobre o indivíduo responsável pela entrega dos recursos enviados pelo açougueiro da Costa da África, morador em Porto Alegre, para a senhora mina, residente em Salvador, sua ex-companheira ou amásia, permite asseverar que os laços e vínculos entre as duas cidades eram estabelecidos, mantidos e fortalecidos por questões comerciais (incluindo o tráfico escravista), familiares e também militares, que se imbricavam. Em sua tese, o historiador José Iran Ribeiro salienta a importância do deslocamento de tropas na manutenção da unidade territorial brasileira

54 AHRS, Coleção Varela, CV-8731, Fé de ofício de João Luiz de Abreu e Silva.

55 CHC/SCMPA, Livro de Óbitos de Livres $n^{\circ} 7$, registro 11147, Óbito de João Luiz de Abreu e Silva enterrado a 11/10/1866, sepultura catacumba $n^{\circ} 106$ da $2^{a}$ ordem. Sua esposa Antônia Carolina faleceu logo em seguida, em 27 de outubro de 1868, de lesão orgânica do coração (branca, 59 anos de idade, natural desta província). CHC/SCMPA, Livro de Óbitos de Livres $n^{\circ} 7$, registro 12602.

56 AHCMPA, Livro $9^{\circ}$ de Casamentos da Paróquia de Nossa Senhora da Madre de Deus, folha 58, Casamento de João Luiz de Abreu Silva Júnior. 
e as "possibilidades e limites para a construção de uma nacionalidade brasileira durante a Guerra dos Farrapos”. ${ }^{57}$ Nas suas pesquisas, Ribeiro dá importância ao recrutamento militar, mostrando como, através dele, indivíduos saíram de suas províncias (de forma voluntária ou compulsória) e se espraiaram por outras, muitas vezes não retornando aos locais de origem. Ribeiro dá ênfase à Bahia, mesmo que diga que o número de recrutados baianos para o combate contra os farrapos foi inferior ao de recrutados em outras províncias. Citando alguns casos individuais de recrutados baianos, Ribeiro trata do então capitão João Luiz Abreu Silva, dizendo que ele era filho do comerciante baiano José Joaquim Silva, "importante comerciante português radicado na Bahia, dono de uma frota de navios de comércio entre o Brasil e Portugal, fundador da primeira casa de seguros daquela província”. ${ }^{58}$

Uma das testemunhas arroladas por Maria Rita para obter a sua parte do inventário de seu filho foi justamente a madrinha de Sabino, Marcolina Maria da Conceição, que se apresenta como nascida na província sulina, solteira, vivendo de negócio, residente também na freguesia de Santana, em Salvador, comadre de Maria Rita. Marcolina confirma que ela, sua mãe Felisberta, Maria Rita e Sabino (que “ainda era de peito") viajaram juntos para Salvador, em 1850, em um navio à vela de propriedade de um João da Costa. Configura-se, assim, a migração de uma família negra, composta por mãe mina e filha crioula, ambas libertas, junto com uma escravizada nagô e seu filho crioulo, de

57 José Iran Ribeiro, “De tão longe para sustentar a honra nacional: Estado e nação nas trajetórias dos brasileiros na Guerra dos Farrapos”, Tese (Doutorado em História Social), Universidade Federal do Rio de Janeiro, Rio de Janeiro, 2009, p. 137.

58 José Iran Ribeiro, “De tão longe para sustentar a honra nacional”, p. 137. Sobre as ligações comerciais entre a Bahia e as charqueadas gaúchas, ver: Jonas Moreira Vargas, "Pelas margens do Atlântico: um estudo sobre elites locais e regionais no Brasil a partir das famílias proprietárias de charqueadas em Pelotas, RS (séc. XIX)”, Tese (Doutorado em História), Universidade Federal do Rio de Janeiro, Rio de Janeiro, 2013. Jonas Moreira Vargas e Paulo Moreira, "Charqueada escravista” in Lilia Schwartz e Flávio dos Santos, Dicionário da escravidão e liberdade, São Paulo: Companhia das Letras, 2018, pp. 149-155. 
Porto Alegre para Salvador, em busca certamente de melhores oportunidades de vida naquela enorme cidade atlântica. ${ }^{59}$

Das Felisbertas de nosso banco de dados das alforrias cartoriais de Porto Alegre, temos uma que apostamos ser a senhora de Maria Rita e Sabino. Trata-se da mina Felisberta, que pagou "o preço e quantia" convencionada com seu escravizador Manoel Gonçalves de Carvalho, e este emitiu um documento de liberdade, em 13 de fevereiro de 1840, registrado em cartório no dia seguinte..$^{60}$ Manoel Gonçalves de Carvalho faleceu em 7 de junho de 1849. Praticamente dois anos antes, em 6 de julho de 1847, ele redigiu suas últimas vontades, dizendo estar em seu perfeito juízo e claro entendimento, porém "adoentado [havi]a anos". ${ }^{61}$ Ele nasceu em Angra, na Ilha Terceira do arquipélago dos Açores, filho legítimo de Francisco Gonçalves Molles e Josefa Mariana, ambos já falecidos na ocasião. Era casado com dona Luiza Joaquina de Jesus, com quem teve cinco filhos, sendo "três machos e duas fêmeas". Manoel pedia para ser conduzido ao cemitério em um caixão do Santíssimo Sacramento, irmandade de que era irmão. Ele tinha, quando de seu falecimento, uma propriedade escrava composta de 21 indivíduos, sendo 9 homens (42,86\%) e 12 mulheres (57,14\%), dos quais, infelizmente, não sabemos a idade. Doze destes escravizados (57\%) são citados explicitamente como africanos, sendo dois cabindas, dois moçambiques, dois angolas, um mina e seis nagôs. Na avaliação de cinco dos homens dessa posse de escravos, consta a profissão ou ofício, sendo um sapateiro, um marceneiro, um pedreiro e dois aprendizes de marceneiro. Manoel Gonçalves de Carvalho era dono de um armazém localizado na rua da Praia, $n^{\circ} 335$, centro de Porto Alegre, que funcionava em imóvel próprio,

59 Outra testemunha arrolada por Maria Rita foi o africano Adão Boaventura, de 68 anos de idade, casado, que vivia de negócio e morava na freguesia de Santo Antônio, em Salvador. Sobre Salvador, ver também: Maria José de Souza Andrade, A mão de obra escrava em Salvador, 1811-1860, Salvador: Corrupio, 1988.

60 APERS, $1^{\circ}$ Tabelionato de Notas de Porto Alegre, Livro de Registros Gerais $n^{\circ} 11$, folha 91, Carta de Alforria de Felisberta.

61 APERS, $1^{\circ}$ Cartório de Órfãos de Porto Alegre, inventário n ${ }^{\circ} 1652$, maço 81, inventariante: Luiza Joaquina de Jesus, Inventário de Manoel Gonçalves de Carvalho, 1849. 
avaliado em oito contos de réis. Sua residência, entretanto, era em um sobrado na rua de Bragança.

No documento que registrou as últimas vontades de Manoel Gonçalves de Carvalho não consta nenhuma alforria. Entretanto, nos cartórios da capital da província sulina foram registrados cinco documentos de liberdade passados por esse português/açoriano. A sua política senhorial, pelo jeito, acompanhava seu habitus de comerciante, já que todos os seus escravos alforriados tiveram que indenizá-lo pecuniariamente (Quadro 1).

Quadro 1

Cartas de alforria de Manoel Gonçalves de Carvalho ${ }^{62}$

\begin{tabular}{c|c|c|c}
\hline Nome & Origem & Data & Condições \\
\hline Faustina & Mina & $10 / 12 / 1825$ & Pagamento, pela escrava, de 128 mil réis. \\
\hline Luiza & & $22 / 10 / 1827$ & Pagamento, pela escrava, de $307 \$ 200$ réis. \\
\hline Luiza & Mina (preta) & $30 / 01 / 1834$ & Pagamento, pela escrava, de $435 \$ 200$ réis. \\
\hline Prisca & Crioula & $25 / 12 / 1841$ & $\begin{array}{c}\text { Pagamento, pela escrava, “pela quantia entre } \\
\text { nós contratada, que recebi ao fazer desta”. }\end{array}$ \\
\hline Marcolina & Crioula & $11 / 12 / 1842$ & $\begin{array}{r}\text { Pagamento, pela escrava, do valor } \\
\text { acertado com seu senhor. }\end{array}$ \\
\hline
\end{tabular}

Temos 20 óbitos de escravizados deste senhor Manoel Gonçalves de Carvalho registrados em Porto Alegre entre 1825 e 1848, sendo 7 africanos e 13 crioulos. Dois africanos eram apenas mencionados pelo continente de origem, do restante um era benguela, um cabinda e três minas. Duas crioulas falecidas eram adultas, mas o restante dos escravizados nascidos no Brasil eram crianças, com entre 18 dias e 6 anos de idade, o que comprova a enorme mortalidade infantil do período, seja de escravizados, forros ou livres. Oito destas crianças crioulas falecidas tinham mães africanas: a benguela Maria

62 APERS, $1^{\circ}$ Tabelionato de Notas de Porto Alegre, Livros de Registros Gerais $\mathrm{n}^{\circ} 8$ (f. $112 v$ ), no 9 (f. 69v), no 12 (f. 128), $n^{\circ} 14$ (f. 60), no 15 (f. 96). 
perdeu dois filhos, as africanas Catarina e Rosa um filho cada uma, a mina Felisberta um, a moçambique Felisberta também um, e a nagô Luiza, dois. ${ }^{63}$ Nas margens de três dessas anotações de falecimento de africanos, estava anotado que foram expedidas certidões dos respectivos óbitos, o que nos faz supor que esse senhor fosse um intermediário do tráfico interprovincial, e que essas certidões fossem remetidas para comerciantes baianos, pernambucanos, cariocas, que lhes haviam enviado essas “mercadorias” para vendas consignadas. Mas nem só de luto se compunha a posse escrava de Manoel Gonçalves de Carvalho: de 1831 a 1848, esse senhor batizou 11 escravizados, sendo 10 destes infantes nascidos de ventres diaspóricos: dois da cabinda Rosa, um da conga Joaquina, cinco das Felisbertas citadas acima, um da angolana Maria e um da africana Laurinda. ${ }^{64}$

Cada vez mais convictos de que esta Felisberta, escravizada e alforriada por Manoel Gonçalves de Carvalho, era a senhora de Maria Rita e Sabino, percebemos que seu nome aparece no registro desses óbitos e batismos mencionados acima. A madrinha de Sabino, que assumiu quando liberta o nome de Marcolina Maria da Conceição, nasceu em 30 de maio de 1838, sendo batizada em 14 de julho do mesmo ano, na Igreja da Madre de Deus de Porto Alegre. Marcolina era gêmea de Petronilha e ambas foram apadrinhadas por Felisbino e Joana, escravizados do mesmo senhor. ${ }^{65}$ Infelizmente, em 18 de fevereiro de 1839, faleceu Petronilha, com apenas 9 meses de idade, filha natural da mina Felisberta, de pneumonia. Como percebemos no Quadro 1, o senhor da crioula Marcolina foi indenizado com o valor com ele “acertado” e ela foi alforriada em 1842, com 4 anos de

63 AHCMPA, Livro $n^{\circ} 3$ (folhas 277, 332v), no 4 (f. 12, 48v, 66, 73, 77, 114), $n^{\circ} 5$ (f. 16, 169, 173v, 178, 180v, 189, 192, 193, 205v).

64 AHCMPA, Livros de registros de batismos da Madre de Deus de Porto Alegre: Livro $n^{\circ} 4$ (folhas 10v, 99 e 139), no 5 (f. 24v) e no 6 (f. 146, 157, 170 e 195).

65 AHCMPA, Livro $n^{\circ} 5$ de Batismos de Escravos da Igreja da Madre de Deus de Porto Alegre, folha 24v, Batismos de Marcolina e Petronilha. 
idade, ato certamente protagonizado por sua mãe mina, a então forra Felisberta Maria da Conceição. ${ }^{66}$

Desde pelo menos o batizado de Sabino, em 1849, a senhora mina Felisberta e a sua filha crioula Marcolina usavam como referências nominais de libertas o sobrenome Conceição. Ou seja, elas optaram por não usar o sobrenome do ex-senhor Gonçalves de Carvalho, o que podia lhes garantir certa segurança, manejando uma referência nominativa que as associaria a um grande comerciante. Elas optaram por se apresentar publicamente com um sobrenome do estoque afro-católico, indicando que suas sociabilidades tangenciavam o espaço das irmandades, sem se limitar a ele. Essa escolha nominal talvez indique que elas já estavam planejando a mudança para Salvador, onde o nome do ex-senhor sulino teria restrita importância.

Talvez a própria aquisição da mina-nagô Maria Rita estivesse incluída nestes planos de mudança de vida e de endereço. Sabemos que muitos forros adquiriram cativos, mas ainda são pouco estudadas as dimensões atlânticas dessa escravização e a sua função e impacto

66 Sobre o protagonismo das minas, ver: Sandra Graham, "Ser mina no Rio de Janeiro do século XIX”, Afro-Ásia, n. 45 (2012), pp. 25-65. Jovani de Souza Scherer, "Experiências de busca pela liberdade: alforria e comunidade africana (Rio Grande, século XIX)”, Dissertação (Mestrado em História), Universidade do Vale do Rio dos Sinos, São Leopoldo, 2008. Natália Garcia Pinto, "Gerações de senzalas, gerações de liberdade: experiências de liberdade em Pelotas/RS, 1850/1888”, Tese (Doutorado em História), Universidade Federal do Rio Grande do Sul, Porto Alegre, 2018. Oyèrónké Oyewùmi, “Conceitualizando gênero: a fundação eurocêntrica de conceitos feministas e o desafio das epistemologias africanas” in Joaze Bernardino-Costa, Nelson Maldonado-Torres e Ramón Grosfoguel (orgs.), Decolonialidade e pensamento afrodiaspóricos, $2^{\mathrm{a}}$ ed. (Belo Horizonte: Autêntica, 2019), pp. 171-181. Manolo Florentino, "Sobre minas, crioulos e a liberdade costumeira no Rio de Janeiro, 1789-1871”, in Manolo Florentino (org.), Tráfico, cativeiro e liberdade (Rio de Janeiro, séculos XVII-XIX) (Rio de Janeiro: Civilização Brasileira, 2005), pp. 331-366. Thiago Leitão de Araújo, "Desafiando a escravidão: fugitivos e insurgentes negros e a política da liberdade nas fronteiras do Rio da Prata (Brasil e Uruguai, 1842-1865)”, Tese (Doutorado em História), Universidade Estadual de Campinas, Campinas, 2016. Juliana Barreto Farias, Mercados minas: africanos ocidentais na praça do mercado do Rio de Janeiro (1830-1890), Rio de Janeiro: Arquivo Geral da Cidade do Rio, 2015. Marcelo Santos Matheus, “A africana mina Maria Francisca do Rosário: escravidão, cor e ascensão social em um contexto fronteiriço (Brasil, segunda metade do século XIX)”, Estudos Iberoamericanos, v. 44 (2018), pp. 501-517. 
na organização da vida dos libertos. Não queremos atenuar a dimensão escravista dessa relação senhora-escravizada, mas não podemos deixar de considerar a etnicidade presente nessa relação, que não se esgota no aspecto mercantil. Seria um dado irrelevante que, na hora de adquirir uma escravizada, a mina forra Felisberta optasse por uma cativa de sua mesma (ou aproximada) "nação”? Felisberta é referida nos documentos a que temos acesso como “mina” e como "africana”, já Maria Rita é alcunhada de “nagô" (1847) e se autodenomina “mina” (1890). Ambas deviam ser provenientes de uma região específica do litoral africano atlântico, a Costa da Mina, e o etnônimo "nagô” indicaria que pelo menos Maria Rita deveria ser falante do iorubá.

A mina Felisberta comprou a mina-nagô Maria Rita do senhor Joaquim José Mendes Ribeiro. Esse senhor já apareceu nesse texto, quando alforriou sua cativa nagô Felicidade, que assumiu o nome de papel de Felicidade Mendes Ribeiro em sua vida de liberta. ${ }^{67}$ Felicidade desposou o também nagô Gregório Ferreira e ambos se disseram da costa da África no testamento que redigiram juntos. Gregório Ferreira era compadre de Antônio José Feliciano, pai de Sabino.

O português Joaquim José Mendes Ribeiro morreu de uma hérnia estrangulada, no dia 5 de janeiro de 1866, em Porto Alegre. Seu óbito o descreve como branco, com 60 anos de idade, casado. ${ }^{68}$ Natural do arcebispado de Braga, Mendes Ribeiro veio para o Rio de Janeiro em janeiro de 1827 e para a província de São Pedro em setembro de 1828. O monte-mor de seus bens chegou a mais de 102 contos de réis, sendo cerca

67 Segundo Antonio Candido, o “nome de papel” seria usado pelos indivíduos em atos públicos, oficiais, enquanto no cotidiano comunitário eles eram identificados e respondiam por composições nominativas diferentes, reconhecidas comunitariamente. Antonio Candido, Os parceiros do rio bonito, São Paulo: Duas Cidades; Editora 34, 2001, p. 278.

68 CHC/SCMPA, Livro de Óbitos de Pessoas Livres $n^{\circ}$ 6, registro 10619, Óbito de Joaquim José Mendes Ribeiro, enterrado a 06/01/1866, sepultura catacumba $n^{\circ} 97$ da $1^{a}$ ordem. AHMPA, auto 102, caixa 209, Habilitação de casamento de Joaquim José Mendes Ribeiro \& Josefina Antônia de Lima, 1831. 
de 21\% concentrados em 30 cativos. ${ }^{69}$ Tinha parte da fazenda Vitória, em Triunfo, a cerca de 76 quilômetros de Porto Alegre, algum gado, um prédio na rua da Praia (centro da capital) e a chácara do Cristal (nos subúrbios de Porto Alegre). Aquela propriedade escrava era composta de 12 crioulos 5 “fêmeas" e 7 "machos”, sendo 3 crianças (de 2 meses, 5 e 8 anos) e 18 africanos - 6 mulheres e 12 homens (entre 35 e 60 anos). Quanto à procedência dos africanos, apenas um deles é referido como “de nação”, sendo o restante dividido em 13 da costa ocidental atlântica (7 minas, 5 nagôs e 1 calabar) e 4 da costa central ( 2 angolas, 1 cabinda e 1 congo). A africanidade da posse escrava desse senhor aparece também nas cartas de alforria que encontramos registradas nos cartórios locais (Quadro 2).

Quadro 2

Cartas de alforria passadas por Joaquim José Mendes Ribeiro ${ }^{70}$

\begin{tabular}{c|c|c|c}
\hline Nome & Data & Procedência & Condições \\
\hline Andreza & $13 / 07 / 1846$ & Mina & Pagamento, pela escrava, de 700\$; \\
\hline Luzia & $16 / 02 / 1850$ & Nação & Pagamento, pela escrava, de 700\$; \\
\hline Antônia (28 anos) & $30 / 08 / 1851$ & Bahia (preta) & $\begin{array}{c}\text { Pagamento, pela escrava, de 700\$; } \\
\text { e em retribuição aos "bons serviços } \\
\text { que sempre me tem prestado”. }\end{array}$ \\
\hline Felicidade & $01 / 01 / 1857$ & Nagô & Pagamento, pela escrava, de 1:400\$. \\
\hline
\end{tabular}

Sabemos, pelo requerimento de 1900, que Maria Rita na época morava em Salvador, província da Bahia, na freguesia de Santana, rua do Gravatá. Sua ex-senhora-moça, Marcolina Maria da Conceição, morava na mesma rua, não sabemos se na mesma casa. No mínimo, portanto, eram vizinhas, “e sabemos que, na sociabilidade africana, vizinho era 'como parte

69 APERS, $2^{\text {a }}$ Vara Cível e Crime, caixa 004.0072, auto 390, Inventário de Joaquim José Mendes Ribeiro.

70 APERS, $2^{\circ}$ Tabelionato de Porto Alegre, Livro de Registros Gerais $n^{\circ} 16$, folha $23 \mathrm{v}$, 14 jul. 1846. APERS, $2^{\circ}$ Tabelionato de Porto Alegre, Livro de Transmissões e Notas $\mathrm{n}^{\circ}$ 59, folha 111, 8 mar. 1850. APERS, $2^{\circ}$ Tabelionato de Porto Alegre, Livro de Transmissões e Notas $n^{\circ}$ 60, folha 39, 3 set. 1851. APERS, $2^{\circ}$ Tabelionato de Porto Alegre, Livro de Registros Gerais nº 16, folha 221v, 1 jan. 1857. 
da família'”, ${ }^{71}$ Não encontramos a alforria de Maria Rita, e supomos que se Marcolina é que serviu de testemunha no inventário de Sabino, então a senhora mina Felisberta Maria da Conceição já havia falecido ou estava muito idosa para prestar depoimento. Felisberta e Maria Rita parecem ter uma boa relação, e disso suspeitamos por residirem na mesma rua (talvez coabitando a mesma casa), por Felisberta se apresentar como sua testemunha e ter anunciado serem comadres (lá do batizado de Sabino, em 1849).

Encontramos a senhora africana Felisberta Maria da Conceição em três escrituras de liberdade registradas em cartório de Salvador (todas elas redigidas por delegação a terceiros), pelas quais sabemos que ela era analfabeta. Na primeira, escrita em 31 de julho de 1857, a "africana liberta” Felisberta, então moradora na Ladeira do Abreu, na freguesia de Santa Ana, beneficiou a africana Henriqueta da Conceição, da qual recebeu 600 mil réis. $^{72}$

As outras duas escrituras de liberdade, supomos, se referiam a Maria Rita, mãe de Sabino. Em 16 de setembro de 1862 Felisberta declara que era "senhora e possuidora de uma cria de nome Justina, crioula, nascida no dia 12 de dezembro do ano passado, filha da minha escrava de nome Rita, nação nagô, a qual forro pelo preço e quantia de duzentos mil réis, em moeda legal”. ${ }^{73}$ Em novembro de 1875, Felisberta Maria da Conceição alforria seu escravizado Antônio, “crioulinho” de 10 anos de idade, filho de Rita, “africana já liberta”. A liberdade é justificada "pelo amor que lhe tenho”, e parece ter sido concedida sem ônus ou condição. ${ }^{74}$

71 Luis Nicolau Parés, "Entre Bahia e a Costa da Mina, libertos africanos no tráfico ilegal” in Giuseppina Raggi, João Figueirôa-Rego e Roberta Stumpf (orgs.), Salvador da Bahia: interações entre América e África (séculos XVI-XIX), Salvador: Edufba; CHAM, 2017, p. 26. Ver também: Milton Guran, Agudás: os “brasileiros” do Benim, Rio de Janeiro: Nova Fronteira, 2000. Pierre Verger. Os libertos: sete caminhos na liberdade de escravos na Bahia do século XIX, São Paulo: Corrupio, 1992.

72 APEB, Livro de Notas do Tabelião, v. 333, fl. 37v, Escritura de liberdade da africana Henriqueta, 3 ago. 1857.

73 APEB, Livro de Notas do Tabelião, v. 357, fls. 73/74v, Escritura de liberdade da crioula Justina, 16 set. 1861.

74 APEB, Livro de Notas do Tabelião, v. 513, fl. 9, Escritura de liberdade do crioulinho Antônio, 5 jan. 1877. 
Assim, sabemos que Maria Rita teve pelo menos mais dois filhos naturais em Salvador que, enquanto avolumavam o patrimônio de sua senhora, engendravam uma família afro-diaspórica. Ainda escravizada, em 1862, Maria Rita conseguiu alforriar sua filha Justina, e em 1875, já liberta, conseguiu que sua senhora Felisberta libertasse seu filho Antônio, "gratuitamente”, falácia senhorial que desdenha do que a mãe havia já trabalhado para obter essa "regalia".

Segundo Richard Graham, em pesquisa já citada neste artigo, diferentemente do que ocorria nos armazéns, a maioria dos vendedores ambulantes de comida de Salvador eram mulheres, fato representativo de uma dimensão atlântica, já que assim era também nos mercados da África ocidental e central. ${ }^{75}$ Segundo Graham, as vendedoras de rua tinham que ser enérgicas, trabalhar duro e desenvolver uma série de habilidades que tinham mais a ver com sua inteligência e criatividade do que propriamente com força física (que também era necessária). Essas mulheres deveriam desenvolver uma relação duradoura com os fregueses e conhecer a etiqueta da pechincha (tanto com os compradores como com os fornecedores):

Ao lidarem com fornecedores e fregueses, as vendedoras tinham de ter múltiplas transações em mente ao mesmo tempo e calcular com rapidez o lucro necessário, levando em conta também tempo e trabalho. Precisavam ter muito cuidado com o que compravam, para manter uma boa reputação pela qualidade dos artigos vendidos, e, portanto, não podiam se dar ao desleixo de ser ingênuas. [...] o exercício de tantas habilidades, os riscos envolvidos e a satisfação de ter concluído um bom negócio deviam dar às vendedoras de rua a confiança, a dignidade, a independência e o dinamismo que vêm da competência comercial e da participação ativa numa economia monetária. Estavam longe de ser vítimas indefesas. ${ }^{76}$

75 Graham, Alimentar a cidade, p. 65; “Ser mina no Rio de Janeiro do século XIX”; Selma Pantoja, “A dimensão atlântica das quitandeiras” in Júnia Ferreira Furtado (org.) Diálogos oceânicos: Minas Gerais e as novas abordagens para uma história do Império ultramarino português, Belo Horizonte: Editora UFMG, 2001, pp. 45-68.

76 Graham, Alimentar a cidade, p. 145. 
Graham, citando a pesquisa de Carlos Soares, menciona que africanos de fala ioruba contrataram um navio no Rio de Janeiro para levá-los de volta à África, logo após o fim do tráfico, em 1850. Os fretadores do navio pretendiam passar pelo porto de Salvador, onde receberiam a bordo outros africanos com idênticos planos. Segundo Graham: "Esses africanos claramente mantinham relações através de centenas de quilômetros, e marinheiros devem ter desempenhado parte crucial em suas comunicações, levando e transmitindo recados e notícias”. ${ }^{77}$

A Freguesia de Santana, em Salvador, era densamente povoada por uma população diversa em termos sociais, étnicos e de status, o que se refletia na configuração das residências: “Ali encontravam-se todos os tipos de casas, desde casarões bem estruturados, com alcovas, varandas e fachadas que evidenciavam a influência europeia, a casas pobres onde vivia a população mais carente, dentre estes descendentes de escravos e libertos". ${ }^{78}$ João José Reis estima que a população de Salvador, quando da eclosão da insurreição malê, em 1835, era de 65.500 habitantes, sendo $42 \%$ de escravizados e 58\% de forros e livres. ${ }^{79}$ Já em 1872, segundo o censo, a capital baiana teria uma população de 125.109 habitantes, sendo Santana, localizada na Cidade Alta, uma das freguesias mais populosas, ao lado das da Sé, São Pedro e Santo Antônio Além do Carmo, com 17.954 moradores. Em 1890, a população da freguesia de Santana subiu para 24.867 habitantes, 10.940 homens (44\%) e 13.927 mulheres (56\%).

77 Graham, Alimentar a cidade, p. 76. Carlos Eugênio Líbano Soares, A negregada instituição: os capoeiras no Rio de Janeiro, 1850-1890, Rio de Janeiro: Departamento Geral de Documentação e Informação Cultural, 1994. Sobre as reinvenções étnicas no Rio de Janeiro, ver: Carlos Eugênio Líbano Soares, Flavio Gomes e Juliana Barreto Farias Gomes, No labirinto das nações: africanos e identidades no Rio de Janeiro, Rio de Janeiro: Arquivo Nacional, 2005.

78 Lucas Stasi, “Expressões leigas da fé católica: irmandades religiosas na Freguesia de Santana em Salvador (1876-1926)”, Dissertação (Mestrado em História), Universidade Federal da Bahia, Salvador, 2017, pp. 30-31.

79 João José Reis, Rebelião escrava no Brasil, São Paulo: Companhia das Letras, 2003, p. 24. 
Quanto ao quesito cor, o censo de 1872 encontra nessa mesma freguesia $38 \%$ de brancos e $62 \%$ de não brancos. ${ }^{80}$

Como já dissemos, não achamos a carta de alforria de Maria Rita. Talvez ela tenha passado de escravizada a uma espécie de agregada da família de ex-senhores. Pelas escrituras de liberdade de seus filhos Justina e Antônio, Maria Rita se alforriou entre 1862 e 1875. Lembremos que a senhora e a senhora-moça eram negras e libertas, assim, a interdependência que havia entre Maria Rita e Sabino com as suas senhoras pode ter tomado matizes um pouco diferentes, tornando-se "parentes por escolha" 81 (lembrando que Sabino fora amadrinhado por sua senhora-moça Marcolina e que Felisberta era africana mina). Trata-se de vínculos demarcados por relações escravistas, parentescos rituais e de nação, interesses e afetos recíprocos afro-femininos, elementos étnico-culturais variados. Isso sem esquecer a questão do gênero: havia obviamente exploração do trabalho e apropriação do produto do ventre escravizado, mas a existência de abuso sexual era improvável. ${ }^{82}$

Libertos podiam ser senhores de escravos da mesma nação; até escravos, frequentemente, se tornavam senhores de outros parentes étnicos. Nada disso impedia que a identidade de nação florescesse, alimentada pela relação com outros grupos situados quer no mesmo patamar, quer nos estratos superiores das configurações socioeconômica e política. Pois identidade é sempre um fenômeno relacional, de contrastes, resulta de estratégias políticas para proteger e fazer avançar o grupo, a despeito de suas diferenças internas, e busca se representar por um complexo sistema

80 Katia M. de Queiros Mattoso, Bahia, século XIX: uma província no Império, Rio de Janeiro: Nova Fronteira, 1992, pp. 95, 110 e 111.

81 Mattoso, Bahia, século XIX, p. 174.

82 Sobre os abusos sexuais sofridos pelas mulheres escravizadas, Toni Morrison comenta que "Hoje em dia, imagino eu, isso seria chamado de estupro; na época chamava-se droit du seigneur, o direito do senhor”. Toni Morrison, A origem dos outros: seis ensaios sobre racismo e literatura, São Paulo: Companhia das Letras, 2019, p. 31. Ver também: Francisco Coelho Duarte Badaró, Fantina: cenas da escravidão, São Paulo: Chão Editora, 2019 (posfácio de Sidney Chalhoub). 
cultural, uma comunidade de sentidos. O próprio processo de trabalho africano na cidade estava pleno de significados culturais. ${ }^{83}$

Segundo Mattoso, em Salvador, "reinava uma relativa liberdade de movimento, pois a própria natureza das tarefas exigia o contato contínuo dos trabalhadores entre si”; a filiação étnica demarcava cartografias na cidade, com as nações possuindo “cantos” próprios: “A rua era também lugar de comer e beber. Desde as primeiras horas da manhã, negras 'ganhadeiras’ começavam a preparar canjica, mingau de tapioca, acaçás bem quentes de farinha de arroz e de milho, arroz com carne-seca, inhame cozido, etc.”. ${ }^{44}$ Assim como as elites, mas certamente com muito menos possibilidades que estas, as famílias populares dependiam de uma situação pluriocupacional, executando ofícios diversos. Maria Rita apresentou-se em 1890 como quitandeira, ofício em que deveria trabalhar em associação com suas ex-senhoras. Já Sabino, quando alforriado por seu pai no início da Guerra do Paraguai, era definido como aprendiz de pedreiro.

João José Reis cita um “censo de libertos” (Relação de Africanos), de 1849, sobre a freguesia de Santana, onde aparecem 168 mulheres, das quais 130 (77\%)

83 Reis, Ganhadores, p. 69. Sobre libertos possuindo escravos, ver: Maria Inês Côrtes de Oliveira, O liberto: seu mundo e os outros, São Paulo: Corrupio, 1988. João José Reis, Domingos Sodré, um sacerdote africano, São Paulo: Companhia das Letras, 2008. Zephyr L. Frank, Dutra's World: Wealth and Family in Nineteenth-Century Rio de Janeiro, Albuquerque: University of New Mexico Press, 2004. Carlos Eugênio Líbano Soares, "Sacramento ao pé do mar: batismo de africanos na freguesia da Conceição da Praia, 1700-1751”, Revista REDE-A, v. 1, n. 1 (2011), pp. 47-70. Kátia Lorena Novais Almeida, Escravos e libertos nas minas do Rio de Contas: Bahia, século XVIII, Salvador: EDUFBA, 2018. Robson Pedrosa Costa, "A Ordem de São Bento e os escravos do Santo: Pernambuco, séculos XVIII e XIX”, Tese (Doutorado em História), Universidade Federal de Pernambuco, Recife, 2013. Daniele Santos de Souza, “'Preto cativo nada é seu?’: escravos senhores de escravos na Cidade da Bahia no século XVIII” in Giuseppina Raggi, João Figueirôa-Rego e Roberta Stumpf (org.). Salvador da Bahia: interações entre América e África (séculos XVI-XIX), Salvador: Edufba; CHAM, 2017, pp. 51-71.

84 Mattoso, Bahia, século XIX, p. 175 e 437. 
trabalhavam vendendo frutas, verduras, comida feita, fazenda, sapatos, louças, etc.; dos 136 homens listados, apenas 19 (14\%) se dedicavam ao comércio. Esses números confirmam que esse setor era principalmente tocado pelas africanas. Os homens estavam ocupados numa maior variedade de atividades. A ocupação mais comum entre eles era a de carregador de cadeiras, em que trabalhavam 26 libertos, seguidos dos 23 listados apenas como "ganhadores". Somados a 7 cangueiros, 11 remadores de saveiro e um marinheiro, resultam em 68 ou $50 \%$ empregados no serviço de transporte. Outros 18\% tinham ocupações mais especializadas, como carpina, pedreiro, sapateiro, alfaiate, que em geral remuneravam melhor. ${ }^{85}$

Usando este mesmo censo, Reis lista os rendimentos individuais dos libertos ali arrolados: pedreiro, 640 réis, e servente de pedreiro, 400 réis. Quitandeiras recebiam rendimentos similares, destacando-se as de peixe, que poderiam chegar a ganhar 1 mil ou 4 mil réis diários. O sistema de ganho podia gerar considerável lucro, visto que 22\% destes libertos africanos e africanas possuíam escravizados. Nenhuma dessas posses escravas tinha mais de oito cativos. A imensa maioria (cerca de 72\%) contava com até dois escravizados, e havia mais mulheres africanas escravistas (35) do que homens (32) ${ }^{86}$

Acessando os dados do mesmo censo de 1849 acima citado, Cecília Moreira Soares percebe que raras africanas libertas se dedicavam ao trabalho doméstico; a maioria se ocupava no "pequeno comércio". ${ }^{87}$ Das 198 africanas listadas, 65 são apontadas como nagôs, 40 como jejes e apenas 5 como minas, mas 81 eram mencionadas só como africanas, o que prejudica a análise da africanidade/etnicidade dessas mulheres forras da freguesia de Santana. Segundo dados apresentados por Soares, 132 africanas forras ocupavam-se em quitandas (35) e mercadejar (97).

85 Reis, Rebelião escrava no Brasil, pp. 367-368.

86 Reis, Rebelião escrava no Brasil, p. 368.

87 Cecília Moreira Soares, “As ganhadeiras: mulher e resistência negra em Salvador no século XIX”, Afro-Ásia, n. 17 (1996), p. 59. 
Das 65 nagôs do censo de 1849, 8 eram quitandeiras, 34 mercadejavam e 2 se ocupavam em negócios.

Esse tipo de atividade não era estranha às negras importadas pelo tráfico negreiro, pois que em muitas sociedades africanas delegavam-se às mulheres as tarefas de subsistência doméstica e circulação de gêneros de primeira necessidade. Muitas ganhadeiras africanas eram provenientes da costa Ocidental da África, onde o pequeno comércio era tarefa essencialmente feminina, garantindo às mulheres papéis econômicos importantes. Esta explicação não exclui mulheres dos grupos bantos, que praticavam igualmente o comércio ambulante em suas terras. ${ }^{88}$

Maria Rita se identifica em seu requerimento de 1900 como preta, africana e mina, enquanto no pagamento da meia sisa, quando foi comprada em 1847 por Felisberta Maria da Conceição, foi descrita como nagô. João José Reis descreve a identidade mina em Salvador como “fluida”, uma expressão vaga que "abarcava nagôs, jejes, haussás e outros grupos do golfo de Benin”. Talvez uma das facilidades de Maria Rita em Salvador - e quem sabe não foi adquirida por isso mesmo - fosse a fluência no ioruba, "uma espécie de língua franca entre muitos africanos que viviam na Bahia”. ${ }^{89}$ Isso facilitaria imensamente o seu trabalho como quitandeira, dialogando com clientes africanos de um largo espectro étnico. ${ }^{90}$ Reis mostra que, ao longo da primeira metade do século XIX, desembarcaram na Bahia 421.184 africanos escravizados, 225 mil deles no "período ilegal”, a grande maioria (cerca de $80 \%$ ) da costa da mina, de maioria nagô. ${ }^{91}$

88 Soares, As ganhadeiras, p. 60.

89 Reis, Rebelião escrava no Brasil, 2003, pp. 308, 329 e 334.

90 Ainda sobre as quitandeiras, ver: Maria Odila da Silva Dias, Quotidiano e poder em São Paulo no século XIX, São Paulo: Brasiliense, 1984.

91 Teria ocorrido, na segunda metade do XIX, um processo de nagoização da população africana de Salvador, "uma população cada vez mais etnicamente concentrada em torno da nação nagô” (Reis, Rebelião escrava no Brasil, pp. 6 e 36). 
O certo é que Maria Rita recebeu aqueles mais de 16 contos de réis da herança de seu filho Sabino em um bom momento. Não sabemos exatamente a estrutura de sua ocupação de quitandeira, mas ela já estava adiantada em anos. Certamente esses recursos a ajudaram - e a sua família - a enfrentar a ancianidade.

\section{Considerações finais}

Às 18 h30 do dia 13 de janeiro de 1856, casaram na Igreja do Rosário, de Porto Alegre, o nagô Fortunato Antônio Rodrigues e a mina Maria Benedita da Conceição, ambos libertos. ${ }^{92} \mathrm{~A}$ africana Benedita alforriou-se em 11 de abril de 1835, sem que a carta passada pelo escravizador José de Oliveira Guimarães expressasse qualquer cláusula ou pagamento. ${ }^{93}$ Já o africano Fortunato se libertou quatro anos depois, em 5 de outubro de 1839, mas teve que indenizar seu senhor Antônio José Rodrigues Ferreira com 400 mil réis, quantia por eles ajustada. ${ }^{94}$ Fortunato conseguiu viver vinte anos liberto, falecendo de encefalite em 24 de maio de 1859, aparentando 60 anos de idade, casado, lenheiro e descrito como de cor preta em seu óbito. ${ }^{95}$

Fortunato, quatro dias antes de morrer, fez o seu testamento, já "doente de cama”. No documento, disse que era natural da costa da África e batizado na Bahia, que não havia conhecido seus pais e tinha em seu poder sua carta de liberdade. ${ }^{96}$ A preta africana Maria Benedita da Conceição faleceu em 11 de novembro de 1870, de gastroepatite,

92 Livro de Casamentos da Paróquia de Nossa Senhora do Rosário, livro 2, folha 27v, Casamento de Fortunato e Benedita. AHCMPA, auto 116, caixa 244, Habilitação de Casamento de Fortunato Antônio Rodrigues \& Maria Benedita da Conceição, 1856.

93 APERS, $1^{\circ}$ Tabelionato de Notas de Porto Alegre, Livro de Registros Diversos $n^{\circ} 10$, folha 189, Escritura de liberdade de Benedita, 15 abr. 1835.

94 APERS, $1^{\circ}$ Tabelionato de Notas de Porto Alegre, Registros Diversos $n^{\circ} 11$, folha $81 \mathrm{v}$, Escritura de liberdade de Fortunato, 7 out. 1839.

95 CHC/SCMPA, Livro de Óbitos de Livres $n^{\circ} 4$, registro 5966, Registro de óbito de Fortunato, enterrado em 24/05/1859, sepultura 127 de entremuros.

96 APERS, Cartório da Provedoria, maço 19, auto 332, Inventário de Fortunato e Benedita, 1870. 
aparentando 70 anos de idade, cor preta e viúva. ${ }^{97}$ Previdente como seu marido já falecido, ela redigiu um testamento sete dias antes de morrer, onde relata que era da costa da mina e indica como testamenteiros, em primeiro lugar, a Joaquim Antônio Maria dos Santos e, em segundo, Antônio José Feliciano, este último seu herdeiro universal. ${ }^{98}$ Ela não indica ter tido filho algum, mas morava com ela um afilhado, José Martino da Silva, que devia ajudá-la em sua velhice e que ela recompensa com alguns móveis de sua casa. ${ }^{99}$ Benedita ainda lembrou de dirigir a sua generosidade para outra afilhada, chamada Maria - "companheira” do segundo testamenteiro e herdeiro, Antônio José Feliciano -, legando-lhe a cama grande e antiga que tinha, "em recompensa dos serviços que me tem prestado”. O patrimônio destes africanos libertos se compunha de um terreno com uma meia-água na rua Direita, no Alto da Bronze, centro de Porto Alegre, alguns móveis e uma escravizada crioula chamada Dionísia, com 48 anos, doente e empregada no serviço doméstico.

Nestes documentos testamentários, percebemos relações mediadas pela questão da diáspora, da etnicidade e da amizade. Pelo relato de Maria Benedita da Conceição, Antônio José Feliciano e Maria já eram “companheiros” (amásios) em 1870 - isso supondo, como acreditamos, que essa Maria fosse a Ana Maria Antônia citada no testamento de 1888. Naquela época, Feliciano já tinha dois filhos, Sabino e Isidoro, mas, segundo seu testamento, ele ainda teria mais cinco: Antônio (nascido por volta de 1874), Maria Antônia (1873), Felicidade (1876), João Antônio (1879) e José Maria (1881). Ou seja, os filhos foram gerados paralelamente à relação de Feliciano com Maria.

97 CHC/SCMPA - Livro de Óbitos de Livres $n^{\circ}$ 8, registro 13946, Óbito de Benedita, enterrada a 11/11/1870, na sepultura 127 de entremuros, quadra dos contribuintes.

98 Joaquim Maria dos Santos era português (Vila de Ançã) e negociante. Quando casou, em 1835, disse que havia saído de sua “pátria” havia 8 anos e foi para a Espanha, França e África “e mais partes, de onde se dirigiu a esta província”, onde estava instalado já fazia quatro anos. AHCMPA, auto 42, caixa 221, Habilitação de casamento de Joaquim Antônio Maria dos Santos \& Bernarda Joaquina de Freitas, 1835.

99 Uma marquesa, com dois baús, sendo o mais pequeno o armário com a louça, uma mesa pequena e cadeiras e mochos. 
Sabemos que a idade dos africanos era mais uma impressão baseada na sua condição física (o padrão era usar o termo “aparenta ter”) do que em uma efetiva cronologia de nascimento. Pela idade declarada quando de sua morte, Feliciano teria 70 anos em 1888 e, portanto, 52 anos em 1870. Ele gasta recursos volumosos para alforriar seus dois primogênitos, Sabino e Isidoro, mas os outros filhos são já de ventre livre, e ele aparentemente não se esforça em antecipar a efetivação de suas liberdades. Que tipo de relação teriam Feliciano e Maria, já que esta se mantém apesar das relações extraconjugais de Feliciano? Seriam esses filhos indicados como "naturais" filhos consanguíneos, ou Sabino estaria assumindo uma paternidade simbólica, como “pai” comunitário?

Em sua tese de doutoramento, o historiador Marcelo Matheus identificou uma rede de africanas minas que se ajudavam mutuamente, na cidade de Bagé, na fronteira do Rio Grande do Sul com o Uruguai, em meados do Oitocentos. Elas compunham uma família extensa, alcunhando-se umas às outras de "manas" e "tias", denominando aquela que tinha ascendência sobre as outras de "tia mina” ou "chica mina”. ${ }^{100}$ Em 1835, no quilombo que vicejou na Serra dos Tapes, cercanias da região charqueadora de Pelotas, na mesma província, os quilombolas aterrorizaram as autoridades com um grupo coeso liderado por um “general”, um “juiz de paz” e três “pais”: o já forro Simão Vergara (Angola e Congo), o preto da Costa Mateus e o crioulo Francisco. O historiador Mário Maestri aponta que essas formas de tratamento deveriam ser "denominativos parentais simbólicos”. ${ }^{101}$

100 Marcelo Santos Matheus, “A produção da diferença: escravidão e desigualdade social ao sul do Império brasileiro (Bagé, c.1820-1870)”, Tese (Doutorado em História), Universidade Federal do Rio de Janeiro, Rio de Janeiro, 2016, p. 267.

101 Mário Maestri Filho, "Pampa negro: quilombos no Rio Grande do Sul” in Flávio dos Santos Gomes e João José Reis (orgs.), Liberdade por um fio: história dos quilombos no Brasil, São Paulo: Companhia das Letras, 1996, p. 330. Caiuá Cardoso Al-Alam, Natalia Garcia Pinto e Paulo Moreira, “Os Calhambolas do General Manoel Padeiro: práticas quilombolas na Serra dos Tapes (RS, Pelotas, 1835)”, São Leopoldo: Oikos, 2013. Em certas comunidades camponesas negras atuais existe o hábito de chamar de "tios" e "tias" os indivíduos mais velhos, como sinal de respeito. Ver Weimer, "A gente da Felisberta”, p. 226. Daisy Macedo de Barcellos et al., Comunidade negra de Morro Alto: historicidade, identidade e direitos constitucionais, Porto Alegre: Editora da UFRGS, 2004, p. 213. 
A carta de Maria Rita fazia parte de uma fonte judiciária ou cartorial, porque foi inserida no interior de um documento produzido pela alçada judiciária, mas a sua produção foi privada e a sua conservação também. Se Sabino guardou a missiva de sua mãe foi porque se tratava de um patrimônio afetivo, que presentificava (e materializava) o afeto trocado e mantido entre eles. ${ }^{102}$ Esse documento foi tornado oficial pela sua inserção em um dossiê documental voltado para a questão da transmissão patrimonial, mas a sua existência era justificada pela manutenção de uma memória familiar.

Podemos pensar que os forros se localizam e se (re)inventam num espaço liminar, "situado no meio das designações de identidade". ${ }^{103}$ Não se avança muito ao pensá-los de forma estanque, absolutamente desvinculados de escravizados e livres, com os quais dialogam e com os quais apresentam aproximações e diferenças. Essas afiliações e distanciamentos são dados pela memória individual e familiar - lembrando que, no jogo da memória, a amnésia (seletiva e às vezes enganosa) tem participação importante, o que antevemos no frequente "desconhecimento" ou "esquecimento" do nome dos pais pelos africanos. ${ }^{104} \mathrm{~A}$ experiência social destes libertos era marcada pela memória traumática da diáspora (direta ou indiretamente) em suas variadas faces, mas também pelas distâncias e rompimentos familiares. Os atores sociais e familiares ali envolvidos muitas vezes estavam distantes geograficamente, o que não pressupõe necessariamente fim ou atenuação do afeto.

O psiquiatra e filósofo Franz Fanon, em capítulo intitulado "A experiência vivida do negro", fala da sensação de ser um "objeto em meio a outros objetos", o que o fazia se sentir enclausurado em uma "objetividade esmagadora". ${ }^{105}$ Evitando o anacronismo, podemos pensar na opressão

102 Weimer, “A Gente da Felisberta”, p. 72.

103 Bhabha, O local da cultura, p. 22.

104 Sobre memória, ver: Michael Pollak, “Memória, esquecimento, silêncio”, Estudos Históricos, v. 2, n. 3(1989), pp. 3-15. Pierre Nora, "Entre memória e história: a problemática dos lugares”, Projeto História, n. 10 (1993), pp. 7-28. Maurice Halbwachs, A memória coletiva, São Paulo: Vértice, 1990. Ulpiano T. Bezerra de Menezes, “A história, cativa da memória? Para um mapeamento da memória no campo das Ciências Sociais”, Revista do Instituto de Estudos Brasileiros, São Paulo, n. 34 (1992), pp. 9-24.

105 Frantz Fanon, Pele branca, máscaras negras, Salvador: Edufba, 2008, p. 103. 
objetiva e subjetiva pela qual passavam os escravizados, vítimas do tráfico transatlântico, da mercantilização de seus corpos, de seus esforços laborais, de seus ventres e dos "produtos” deles. Sabino guardou a carta da mãe como um artefato de desejo e afeto, e a inseriu em um acervo documental privado, com documentos comprobatórios e pessoais. Maria Rita (assim como José Antônio) era testemunha do drama e do trauma da escravização e da diáspora. Sua correspondência traz que tal trauma não lhe amorteceu a sensibilidade, nem o carinho pelo filho. A função primária daquele bilhete era trocar informações e carinhos, assegurando que os laços permaneciam intactos, machucados pela distância mas ainda resistindo a mais uma desterritorialização. Maria Rita “perdeu” Sabino quando esse migrou para o encontro do pai, e ainda sobreviveu ao filho, recebendo a notícia que muito a lastimou. ${ }^{106}$

Muito se avançou no Brasil - principalmente através dos programas de pós-graduação - na análise do passado escravista, e para isso foram muito importantes os pressupostos teóricos do marxista E. P. Thompson, principalmente do seu conceito de experiência social. Talvez pela matriz marxista desse conceito, pouco se cogitou que ele remetia também a uma análise das subjetividades dos agentes. Segundo Thompson:

As pessoas não experimentam sua própria experiência apenas como ideias, no âmbito do pensamento e de seus procedimentos, ou (como supõem certos praticantes teóricos) como instinto proletário, etc. Elas também experimentam sua experiência como sentimento e lidam com esses sentimentos na cultura, como normas, obrigações familiares e de parentesco, e reciprocidades, como valores ou (através de formas mais elaboradas) na arte ou nas conviçções religiosas. Essa metade da cultura (e é uma metade completa) pode ser descrita como consciência afetiva e moral. ${ }^{107}$

106 Reis destaca que os nagôs - etnia hegemônica em Salvador na segunda metade do Oitocentos - vinham de uma situação africana política e culturalmente heterogênea, marcada pela submissão a diferentes reinos, os quais se atritavam entre si. Entretanto, no exílio brasileiro, uma “combinação de experiências traumáticas” os irmanavam, além de "língua e mitos de origem comuns” (Reis, Ganhadores, p. 70).

107 Edward P. Thompson, A miséria da teoria, Rio de Janeiro: Zahar, 1981, p. 189. 
Em artigo recente, publicado na revista Mundos do Trabalho, o historiador Fernando Pureza provocou um criativo diálogo entre as obras "do historiador marxista E. P. Thompson e da filósofa e militante negra norte-americana Angela Davis", ${ }^{108}$ envolvendo alguns conceitos-chave das duas produções intelectuais, entre eles o de experiência. Pureza destaca como a perspectiva de Davis enriquece o conceito thompsoniano, contemplando "opressões outras que constroem sentidos plurais que afetam o mundo do trabalho, mas vão além dele". ${ }^{109}$

Mas chama atenção o emprego do termo que Davis sugere, pois sua amplitude retoma a ideia de que o conceito não pode se resumir à exploração do trabalho escravo unicamente. De fato, a experiência envolveria uma categoria que ao mesmo tempo em que estivesse relacionada à opressão a qual a mulher escravizada estava sujeita, ela também apostaria em questões como, por exemplo, a fruição de uma vida doméstica na qual poderia ser possível construir sentidos e sentimentos contrários à exploração do trabalho escravo. Em outras palavras, o sentido da experiência que Davis resgata é a de sujeitos capazes de produzir os próprios sentidos de sua vida (seja por meio do trabalho, dos ritos, das festas, dos afetos), não obstante toda a violência que recai sobre elas. ${ }^{110}$

Pureza destaca que, tanto para Thompson como para Davis, os agentes sociais não mantêm uma relação passiva com a experiência, mas a transformam criativamente e são transformados por ela, em ações individuais e sobretudo coletivas, gerando o que o autor alcunhou como “experiência como sentimento”. ${ }^{111}$

108 Fernando Cauduro Pureza, "Cruzando olhares: estabelecendo diálogos entre E.P. Thompson e Angela Davis”, Revista Mundos do Trabalho, v. 11 (2019), p. 5.

109 Trata-se de "formas específicas de opressão" (Angela Davis, Mulheres, raça e classe, São Paulo: Boitempo, 2016, p. 159).

110 Pureza, “Cruzando olhares”, p. 5.

111 Pureza, “Cruzando olhares”, p. 4. Em seu último livro, o historiador João José Reis, quando fala da música e dos cantos que acompanhavam a labuta dos ganhadores de Salvador, cadenciando o ritmo de trabalho e aliviando a estafa diária, argumenta que 
Feliciano, ao pagar pela liberdade de seu filho Sabino e trazê-lo para perto de si, mescla paternidade e previdência com relação à velhice, conseguindo em seu primogênito um arrimo para a sua ancianidade. Lembremos que ele também alforriou o filho Isidoro Antônio Feliciano, quando esse tinha apenas 8 anos de idade, em 1874. Feliciano tinha a seu lado, portanto, dois filhos maiores, que o ajudaram a cuidar de si e dos seus meios-irmãos e irmãs. O bem-estar das famílias (ainda mais de escravizados e forros) demandava planejamentos complexos, que envolviam questões geracionais, com o cuidado com parentes que não podiam (ou pouco podiam) cuidar de si, como crianças e idosos. Isto nos faz pensar em como estas experiências sociais afro-diaspóricas só são (parcialmente) entendidas se miradas na pluralidade das posições destes agentes. Sem mencionar o termo "interseccionalidade”, Homi Bhabha comenta sobre as diversas posições dos sujeitos e como elas se estruturam dialogicamente:

O afastamento das singularidades de "classe" ou "gênero" como categorias conceituais e organizacionais básicas resultou em uma consciência das posições do sujeito - de raça, gênero, geração, local institucional, localidade geopolítica, orientação sexual - que habitam qualquer pretensão à identidade no mundo moderno. ${ }^{112}$

com isso eles afirmavam a sua humanidade, combatendo a "coisificação subjetiva implícita no projeto escravocrata de considerá-los coisa a ser comprada, vendida, hipotecada, doada, alugada, simples máquina de trabalho” (Reis, Ganhadores, p. 76).

112 Bhabha, O local da cultura, pp. 19-20. Sobre interseccionalidade, ver: Kimberle Crenshaw, Documento para o encontro de especialistas em aspectos da discriminação racial relativos ao gênero, Revista Estudos Feministas, 2002, vol. 10, n.1, pp.171-188; Adriana Piscitelli, "Interseccionalidade, categorias de articulação e experiências de migrantes brasileiras”, Sociedade e Cultura, v. 11, n. 2 (2008), pp. 263-274. Priscilla Almaleh, “Ser mulher: cotidianos, representações e interseccionalidades da mulher popular (Porto Alegre 1889-1900)”, Dissertação (Mestrado em História), Universidade do Vale do Rio dos Sinos, São Leopoldo, 2018. Anne McClintock, Couro imperial: raça, gênero e sexualidade no embate colonial, Campinas: Editora Unicamp, 2010. Para uma análise interseccional da sociedade escravista, ver: Bruna Letícia de Oliveira dos Santos, “'Os brancos não falam a verdade contra mim. Porque ele é homem e não havia de passar o trabalho que as fêmeas passam': Maria Rita e a interseccionalidade de mulheres escravizadas (comarca de Rio Pardo XIX)”, Dissertação (Mestrado em história), Universidade do Vale do Rio dos Sinos, São Leopoldo, 2020. Marina Camilo Haack, "Sobre silhuetas negras: experiências 
A questão é, segundo Bhabha, ir "além das narrativas de subjetividades originárias e iniciais”, percebendo as “articulações de diferenças culturais", entrelugares que "fornecem o terreno para a elaboração de estratégias de subjetivação - singular ou coletiva - que dão início a novos signos de identidade e postos inovadores de colaboração e contestação, no ato de definir a própria ideia de sociedade”. ${ }^{113}$

Assim, análises interseccionais têm que pensar e contemplar a questão etária, pois a administração da velhice era parte fundamental da existência e sobrevivência de indivíduos, em um momento histórico em que não havia proteção pública para a ancianidade. Era essencial o bom “uso” das relações familiares como arrimo em momentos marcados pela diminuição das capacidades físicas e psicológicas que garantiam o sustento via trabalho manual, mesmo que especializado. Nesse sentido, logicamente, a troca de afetos visava produzir ajuda mútua em termos de sobrevivência física e psicológica. Por outro lado, registremos que a ancianidade era relevante nas hierarquias sociais africanas e, assim, as famílias e comunidades afro-diaspóricas certamente preocupavam-se com o bem estar de seus mais velhos.

Os escravizados ou libertos incapacitados fisicamente, seja pelo trabalho manual intenso para o sustento das famílias senhoriais ou pela velhice, dependiam da ajuda de seus familiares e parentes ou eram obrigados a recorrer à mendicância. ${ }^{114}$ Escravos não necessariamente velhos, mas cuja saúde precária os tornava inúteis aos senhores, eram dispensados do cativeiro. Afinal, os senhores preferiam não arcar com os gastos com remédios, médicos e enterros: que a caridade pública (ou seus parentes) os tratassem e enterrassem em cova rasa. A escrava natural do Congo Maria da Conceição recebeu alforria em $1^{\circ}$ de novembro de 1836 , de seu senhor José Antônio dos Santos Lara, sem qualquer ônus, "não só pelos bons serviços que até agora me tem prestado e a minha família, bem como por

e agências de mulheres negras escravizadas (Cachoeira, 1850/1888)”, Dissertação (Mestrado em História), Universidade do Vale do Rio dos Sinos, São Leopoldo, 2019.

113 Bhabha, O local da cultura, p. 20.

114 Walter Fraga Filho, Mendigos, moleques e vadios na Bahia do século XIX, São Paulo: Hucitec; Salvador: Edufba, 1996. 
se achar gravemente doente de tísica [tuberculose], e não querendo que esta moléstia contagiosa grasse na mesma família e casa onde está habitando”, e para que possa "ir para onde quiser tratar de sua saúde como senhora de si”. O angolano Domingos, aos 60 anos de idade, recebeu a graça de sua alforria dada por seu escravizador Joaquim Manuel do Nascimento em 4 de abril de 1861. Seu senhor achou conveniente anotar naquele documento de liberdade que Domingos o servia há tempos e que o alforriava "muito a minha vontade e por achar-se em falta de saúde e para poder pedir suas esmolas aos fiéis de Deus, para poder ir vivendo”. ${ }^{115}$

Mesmo com limites, Maria Rita exerceu a sua maternidade (escravizada), tendo seu filho primogênito por perto até este atingir a idade adulta, quando migrou ao encontro do pai. Óbvio que como mãe e filho eram escravizados (mesmo que de uma senhora africana e forra), e essa maternidade foi exercida com vários limites, uma vez que o poder decisório se concentrava nas mãos da dona dos cativos. ${ }^{116}$ Certamente, não era monopólio dos egressos diretos da diáspora transatlântica a aversão a novas desterritorializações, principalmente quando elas separavam famílias, parentes e amigos, o que frequentemente ocorria. Sem que queiramos diminuir o impacto desses momentos traumáticos, o caso de Sabino, Feliciano e Maria Rita nos auxilia a constatar que às vezes esses rompimentos conseguiam ser atenuados ou remediados. A distância, por vezes, não pressupunha o silenciamento das comunicações e a quebra

115 APERS, $2^{\circ}$ Tabelionato de Porto Alegre, Livro de Registros Diversos $n^{\circ} 17$, folha 88, Faxinal de São João, 6 abr. 1861.

116 Sobre a maternidade escravizada, ver: Camillia Cowling, Concebendo a liberdade: mulheres de cor, gênero e a abolição da escravidão nas cidades de Havana e Rio de Janeiro, Campinas: Editora Unicamp, 2018. Mariana Muaze, "Maternidade silenciada: amas de leite no Brasil escravista, século XIX” in Helen Osório e Regina Xavier, Do tráfico ao pós-abolição: trabalho compulsório e livre e a luta por direitos sociais no Brasil, São Leopoldo: Oikos, 2018; Mariana P. Candido e Adam Jones (org.), African Women in the Atlantic World: Property, Vulnerability \& Mobility, 1660-1880, Suffolk: Boydell and Brewer, 2019. Lamonte Aidoo, Slavery Unseen: Sex, Power, and Violence in Brazilian History, Durham; Londres: Duke University Press, 2018. Lorena Féres da Silva Telles, “Teresa Benguela e Felipa Crioula estavam grávidas: maternidade e escravidão no Rio de Janeiro (século XIX)”, Tese (Doutorado em História), Universidade de São Paulo, São Paulo, 2018. 
absoluta das relações sociais e afetivas. Aliás, como vimos na carta de Sabino com sua mãe mina, moradora em Salvador, o carinho e o respeito se mantiveram entre eles.

No livro Provas de liberdade, os historiadores Rebecca Scott e Jean Hébrard propõem uma micro-história em movimento, seguindo "uma cadeia interconectada de eventos definidos pelo itinerário de uma família”. Eles destacam que “não há nada 'micro’ no mundo atlântico do século XIX, mas mesmo nesse quadro tão amplo, a análise mais profunda pode surgir da intensa atenção ao particular”. Reiteradamente, alguém da família analisada "usou papel e tinta, ou fez com que outros usassem, construindo um arquivo de movimento e de memória”, pois "palavras protegiam e palavras podiam escravizar”. ${ }^{117}$ Mas o bilhete que destacamos nesse artigo evidencia que a palavra também estrutura e mantém laços afetivos, alicerça memórias e é substrato de experiências de afirmação e autonomia. Guardados como objetos de valor, esses documentos presentificavam pessoas estimadas e sustentavam sentimentos familiares, em relações em que a distância e a ausência magoavam, mas não diluíam os apegos. ${ }^{118}$

Recebido em 20 fev. 2020

Aprovado em 5 out. 2020

doi: 10.9771/aa.v0i62.35608

117 Rebecca Scott, Jean Hébrard, Provas de liberdade: uma odisseia atlântica na era da emancipação, Campinas: Unicamp, 2014, p. 19 e 35.

118 Livros, roupas, cartas, imagens de santos e retratos são itens perfeitos como "objetos de afeto", trocados e mantidos entre pessoas de um mesmo grupo de afinidade. Véronique Dassié, Objects d'affection: une ethnologie de l'intime, Paris: Éditions du Comité des travaux historiques et scientifiques, 2010. Ângela de Castro Gomes, “A guardiã da memória”, Acervo, Rio de Janeiro, v. 9, n. 1-2 (1996), pp. 17-30. Olivia Silva Nery, “Objeto, memória e afeto: uma reflexão”, Revista Memória em Rede, Pelotas, v. 10, n. 17 (2017), pp. 144-161. 
O objetivo deste artigo é analisar a continuidade e a estrutura dos laços familiares em situações de diáspora e desterritorialidade. A diáspora transatlântica não esgota a questão dos traumas e desvinculamentos acarretados pela escravidão. Trazidos escravizados para o Brasil, os africanos eram ainda vítimas de transações mercantis que os faziam ir, junto com suas famílias aqui criadas, para diferentes províncias do Império, conforme as necessidades locais e os rumos do tráfico interprovincial. Alguns documentos, mesmo que residuais, nos permitem mesclar agência e estrutura na sociedade escravista, e pensar como os arranjos familiares e afetivos se mantinham. A ideia é acompanhar a trajetória de alguns indivíduos africanos e seus filhos crioulos, cogitando como eles construíam e mantinham seus arranjos afetivo-familiares.

Escravidão | Diásporas | Família | Alforrias

\section{Accept the Blessing and Tight Hug of Your Caring Mother: \\ SLAVEry, Diaspora ANd the LongeVity of Family TIES (Porto Alegre, Salvador, 19th Century)}

This paper analyzes the continuity and structure of family ties in diasporic and deterritorial contexts. The transatlantic diaspora does not exhaust the trauma caused by the shattering of affective ties shattered by enslavement. After arriving in Brazil as slaves, Africans were further victimized by commercial transactions that forced them (as well as members of their families created here) to move to different provinces of the Empire, caught up in the web of the inter-provincial slave trade. Archival evidence, although fragmentary and indirect, provides clues about the mechanisms of agency and structure in slave society, making it possible to understand how family and affective arrangements were maintained. The idea is to follow the trajectories of some Africans and their Creole (i.e., Brazilian-born) children, examining how they built and maintained their affective-family arrangements.

Slavery | Diasporas | Family | Manumissions 